\title{
Health-related quality of life among community-dwelling people aged 80 years and over: a cross-sectional study in France
}

\author{
Isabelle Jalenques ${ }^{1 *} \mathbb{D}$, Fabien Rondepierre ${ }^{2}$, Chloé Rachez ${ }^{2}$, Sophie Lauron ${ }^{3}$ and Candy Guiguet-Auclair ${ }^{4}$
}

\begin{abstract}
Background: The proportion of people living to a very old age is continuously increasing. One of the possibilities explored in policies and services to meet this health and societal challenge is to encourage the very old to continue living at home. This initiative is in line with the wishes of most elderly people. However, owing to the great changes that occur during old age attention should be paid to health-related quality of life (HRQOL). The aims of this study were to assess HRQoL in French community-dwelling people aged 80 years and over and to investigate the sociodemographic and health characteristics and life events associated with HRQOL.

Methods: A cross-sectional study was conducted in France to assess the HRQoL of people aged 80 years or more living at home. All people recruited were sent a letter explaining the aim of the study and requesting their consent to take part. Those who accepted then received a series of sociodemographic and medical questionnaires, a questionnaire concerning life events of the previous 12 months and the LEIPAD questionnaire, which assesses HRQOL in elderly people.

Results: The data of 184 participants (54.9\% female) with a mean age of 83.9 years (almost $40 \%$ older than 85 years), were analysed. Low scores, indicating better HRQoL, were obtained on the 'Self-Care' and 'Depression and Anxiety' scales with 50.9 and $40.8 \%$ of responders, respectively, having the minimum score of zero. The highest score was found on the 'Sexual Functioning' scale, with 59.1\% of participants having the maximum score of 100. Elderly females declared a significantly less satisfactory HRQoL. Deteriorating health, an unsatisfactory environment, not being able to drive, perceived modest income and financial worries negatively affected HRQoL.

Conclusion: Identifying factors in our study that are potential determinants of HRQoL would be of direct benefit for individuals. Concrete public policy initiatives concerning means of transport, living environment and financial resources could then be implemented to improve the HRQoL of very old community-dwelling individuals.
\end{abstract}

Keywords: Health-related quality of life, Elderly people, Older adults, Eighty and over, Ageing, Community-dwelling elderly people, LEIPAD

\footnotetext{
*Correspondence: ijalenques@chu-clermontferrand.fr

'Université Clermont Auvergne, CHU Clermont-Ferrand, Service de Psychiatrie de l'Adulte A et Psychologie Médicale, Centre Mémoire de Ressources et de Recherche, 58 rue Montalembert, Cedex 1, 63003 Clermont-Ferrand, France

Full list of author information is available at the end of the article
}

(C) The Author(s). 2020 Open Access This article is licensed under a Creative Commons Attribution 4.0 International License, which permits use, sharing, adaptation, distribution and reproduction in any medium or format, as long as you give appropriate credit to the original author(s) and the source, provide a link to the Creative Commons licence, and indicate if changes were made. The images or other third party material in this article are included in the article's Creative Commons licence, unless indicated otherwise in a credit line to the material. If material is not included in the article's Creative Commons licence and your intended use is not permitted by statutory regulation or exceeds the permitted use, you will need to obtain permission directly from the copyright holder. To view a copy of this licence, visit http://creativecommons.org/licenses/by/4.0/ The Creative Commons Public Domain Dedication waiver (http://creativecommons.org/publicdomain/zero/1.0/) applies to the data made available in this article, unless otherwise stated in a credit line to the data. 


\section{Background}

The populations of industrialised countries have seen a major increase in the last few decades in the number of people living to a very old age. At present, $5.3 \%$ of the population in Europe is aged 80 years and over [1] and this age group is currently the fastest growing on the continent and will continue to be so up to 2050 [2]. To meet the challenges that come with this trend, one of the areas of interest explored in policies and services is to encourage living in the community until very old age. This is in line with the wishes of most older people in Western countries, who prefer to live in their own familiar environment as long as possible rather than in institutions [3-5]. Such initiatives would also increase the ability of the health care systems to bear the financial costs [4]. However, owing to the great changes that occur in the long period of life that now extends beyond the age of 65, particularly in terms of health, particular attention needs to be paid to aged people's quality of life (QoL). In 2014, total life expectancy at 65 years was 18.2 years, including 8.6 years with no activity restrictions for men, and 21.6 years, including 8.6 with no activity restrictions for women [6].

The quality of life is a broad concept covering all aspects of human activity. Health, the environment and social domain greatly influence the life of elderly people [4]. Health-related quality of life (HRQoL) is a reflection of the way that individuals perceive and react to their health-related factors, such as physical, functional, emotional, and mental well-being and to the nonmedical aspects of their lives such as family, friends and activities [7]. HRQoL and its determinants are therefore of interest to the individual from a medical and social point of view but also in shaping health policy [7]. Thus, measuring the HRQoL can be useful for studying some factors influencing housing decisions among elderly people and assessing how to act on these factors to promote the home support desired by the major part of elderly people and in the policies of many countries [5]. Measuring HRQoL of elderly people can also be useful when developing and then monitoring policy initiatives that are part of the dynamics of the Age-friendly Environments in Europe (AFEE) project [3]; for example by making it possible to assess the links between the physical or social environment and different dimensions of HRQoL. Precise and detailed HRQoL data from sufficiently large sample sizes of community-dwelling people aged 80 years are potentially of great interest but currently are scarce.

We assessed the HRQoL of community-dwelling elderly people (EP) aged 65 years and over in an earlier work [8] but, as in other studies, the number of participants aged 80 years and over was low (32 in our study) [9-11]. Among other studies, a Brazilian team investigated the quality of life of a community-dwelling population aged 60 years and over using the WHOQOLBREF and the WHOQOL-Old. Of the 317 participants recruited $15.4 \%$ were octogenarians but the study gave no specific results for this subgroup [12]. In Europe, the very few recent studies involving community-dwelling people aged 80 years and over, all used the generic EuroQol five dimension scale (EQ-5D). One assessed people aged 75 years and over in six European countries using in addition the SF-12 questionnaire [13]; another, conducted in Switzerland, assessed people aged 65 years and over of whom $41 \%$ were 80 years old or more [14]; and a third assessed Dutch people aged 65 years and over of whom $11.8 \%$ were octogenarians [15]. In three of these studies, data on comorbidities were scarce or lacking. To our knowledge no recent study assessing HRQoL using an instrument specifically aimed at EP has been made in European community-dwelling people aged 80 years and over.

To assess HRQoL in older people, specific instruments, which are more suitable than generic ones because of their item relevance and better acceptability, have been developed and provide particularly useful information. They allow an easy individual assessment of older people's HRQoL and can be used for medical and psychosocial interventions, as described by Xiao-Jun Lin et al. [7] Some of them have shown particularly interesting psychometric properties [16]. They include the LEIPAD, an acronym derived from the first two of the three universities involved in its development, LEIden in the Netherlands and PADua in Italy, under the auspices of the European office of World Health Organization. The LEIPAD is a brief self-administered HRQoL questionnaire developed specifically for community-dwelling EP and validated for French speaking people aged 80 years and over $[17,18]$.

Thus, the aims of this original study were first to measure HRQoL in a larger sample of communitydwelling people aged 80 years or over using a selfadministered questionnaire touching on various aspects of daily life specifically adapted to EP, the LEIPAD questionnaire, and second to study its association with sociodemographic and medical characteristics and life events of this age group.

\section{Methods \\ Study design}

This cross-sectional study was conducted in France to evaluate HRQoL in EP aged 80 years of age and over who were not residents of an institution. The participants were picked at random (simple random sampling using random number tables) from electoral lists provided by the municipalities of six town councils (rural, semi-urban and urban) in the region of Auvergne 


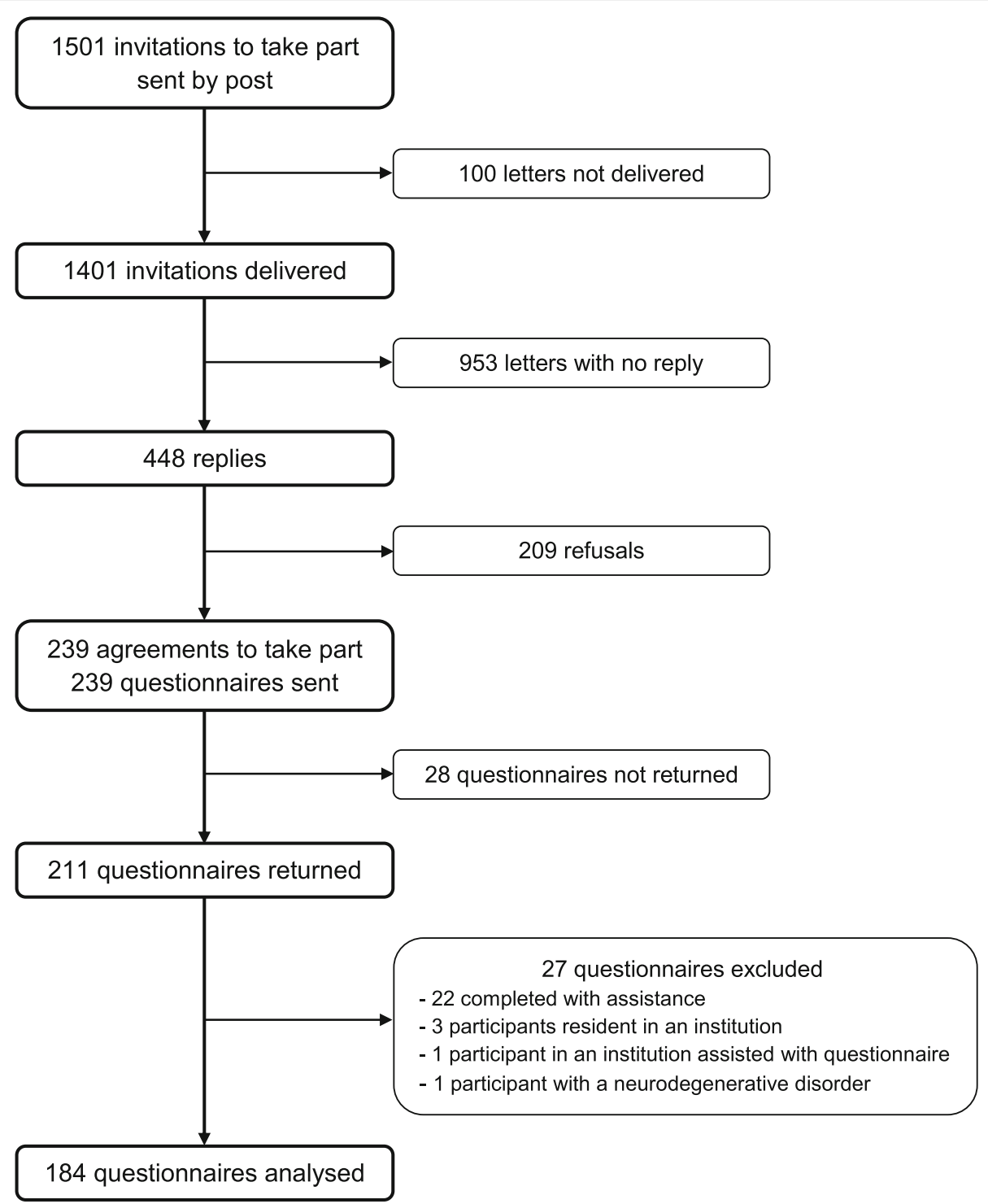

Fig. 1 Organisation chart of participation in the study [18]. Of the 1501 people invited to take part, 448 (32\%) replied to the request (100 letters were not delivered) with 239 accepting (53.3\%) and 209 declining (46.7\%). Of the 239 questionnaires sent to those who accepted to take part, 211 (88.3\%) were returned. Of the latter, 27 were then excluded because they did not fulfil the inclusion criteria, leaving therefore 184 questionnaires to be analysed

(central France). In all, 2064 people were eligible, of whom 1501 were randomly selected to take part in the study. The sample size was calculated for a previous publication validating the LEIPAD questionnaire [18].

All potential participants were sent a letter explaining the aim of the study and requesting them to give consent to take part. Those who accepted then received a set of questionnaires, a letter detailing the procedure to be followed and a prepaid envelope in which to return the questionnaires.

The project was approved by the French regional ethics committee 'Comité d'Ethique des Centres d'Investigation Clinique de l'Inter-région Rhône-Alpes-Auvergne - CE-
CIC Grenoble' (IRB 00005921) and conducted according to the principles expressed in the Declaration of Helsinki. All participants enrolled gave their written informed consent.

\section{Participants}

To be included the participants had to be aged 80 years or over, living at home, not suffering from dementia or any other neurodegenerative disorder and capable of completing the self-report questionnaires without assistance.

Once all the data had been collected, we excluded from analysis participants who had not replied to the 
Table 1 Characteristics of the respondents $(n=184)$

\begin{tabular}{|c|c|c|c|c|}
\hline & Female & Male & Total & \\
\hline & $n(\%)$ & $n(\%)$ & $n(\%)$ & $p$-value \\
\hline \multicolumn{5}{|l|}{ Gender } \\
\hline Female & & & $101(54.9 \%)$ & \\
\hline Male & & & $83(45.1 \%)$ & \\
\hline \multicolumn{5}{|l|}{ Age (years) } \\
\hline mean (SD) & $84.5(3.6)$ & $83.2(2.8)$ & $83.9(3.3)$ & 0.0134 \\
\hline $\min -\max$ & $80-95$ & $80-90$ & $80-95$ & \\
\hline Marital status & & & & $<0.0001$ \\
\hline Never-married, widowed, divorced & $63(64.3 \%)$ & $12(14.5 \%)$ & $75(41.4 \%)$ & \\
\hline Married or living with a partner & $35(35.7 \%)$ & 71 (85.5\%) & $106(58.6 \%)$ & \\
\hline Educational level & & & & 0.6040 \\
\hline Pre-high school & $80(80.0 \%)$ & $63(76.8 \%)$ & $143(78.6 \%)$ & \\
\hline High school or higher & $20(20.0 \%)$ & 19 (23.2\%) & 39 (21.4\%) & \\
\hline Living arrangement & & & & $<0.0001$ \\
\hline Alone & $59(58.4 \%)$ & $16(19.3 \%)$ & $75(40.8 \%)$ & \\
\hline Not alone & $42(41.6 \%)$ & $67(80.7 \%)$ & 109 (59.2\%) & \\
\hline Driving a car & & & & $<0.0001$ \\
\hline Yes & $33(34.0 \%)$ & $76(95.0 \%)$ & $109(61.6 \%)$ & \\
\hline No & $64(66.0 \%)$ & $4(5.0 \%)$ & $68(38.4 \%)$ & \\
\hline Hospital admission during the previous 12 months & & & & 0.1017 \\
\hline Yes & $18(18.4 \%)$ & $23(28.8 \%)$ & $41(23.0 \%)$ & \\
\hline No & $80(81.6 \%)$ & $57(71.3 \%)$ & $137(77.0 \%)$ & \\
\hline \multicolumn{5}{|l|}{ Life events during the previous 12 months } \\
\hline Illness & $27(27.8 \%)$ & $25(31.3 \%)$ & $52(28.3 \%)$ & 0.6196 \\
\hline Poor health & $25(26.6 \%)$ & $20(25.0 \%)$ & $45(24.5 \%)$ & 0.8107 \\
\hline Daily care of a relative or friend & $12(12.9 \%)$ & $16(20.0 \%)$ & $28(15.2 \%)$ & 0.2064 \\
\hline Problem(s) with spouse or partner & $5(5.4 \%)$ & $6(7.5 \%)$ & $11(6.0 \%)$ & 0.5682 \\
\hline Bereavement & $25(26.9 \%)$ & $15(18.8 \%)$ & $40(21.7 \%)$ & 0.2059 \\
\hline Serious illness of a relative or friend & $23(24.7 \%)$ & $26(32.5 \%)$ & $49(26.6 \%)$ & 0.2582 \\
\hline Problem(s) with offspring & 19 (20.4\%) & $8(10.0 \%)$ & $27(14.7 \%)$ & 0.0595 \\
\hline Relational problem(s) with friends or relatives & $8(8.6 \%)$ & $2(2.5 \%)$ & $10(5.4 \%)$ & 0.1091 \\
\hline Unsatisfactory environment & $6(6.5 \%)$ & $7(8.8 \%)$ & $13(7.1 \%)$ & 0.5675 \\
\hline Perceived modest income & 37 (39.8\%) & $17(21.3 \%)$ & $54(29.3 \%)$ & 0.0087 \\
\hline Financial worries & $10(10.8 \%)$ & $7(8.8 \%)$ & $17(9.2 \%)$ & 0.6591 \\
\hline
\end{tabular}

Statistical significance is shown in bold type

questionnaire unaided (identified by an item about whether they completed the questionnaires alone or with help) and those suspected of having a neurodegenerative disorder (identified by two items concerning health problems and current medical treatment).

\section{Data collection}

Sociodemographic characteristics of the EP (gender, age, marital status, educational level, living status, ability to drive, hospital admission during the previous 12 months), their current health problems according to the ICD-10 classification, treatment being taken during the study, and events that may have disrupted their life in the previous 12 months (illness, poor health, daily care of a relative or friend, problem(s) with spouse or partner, bereavement, serious illness of a relative or friend, problem(s) with offspring, relational problem(s) with friends or relatives, moving house, environment perceived as 


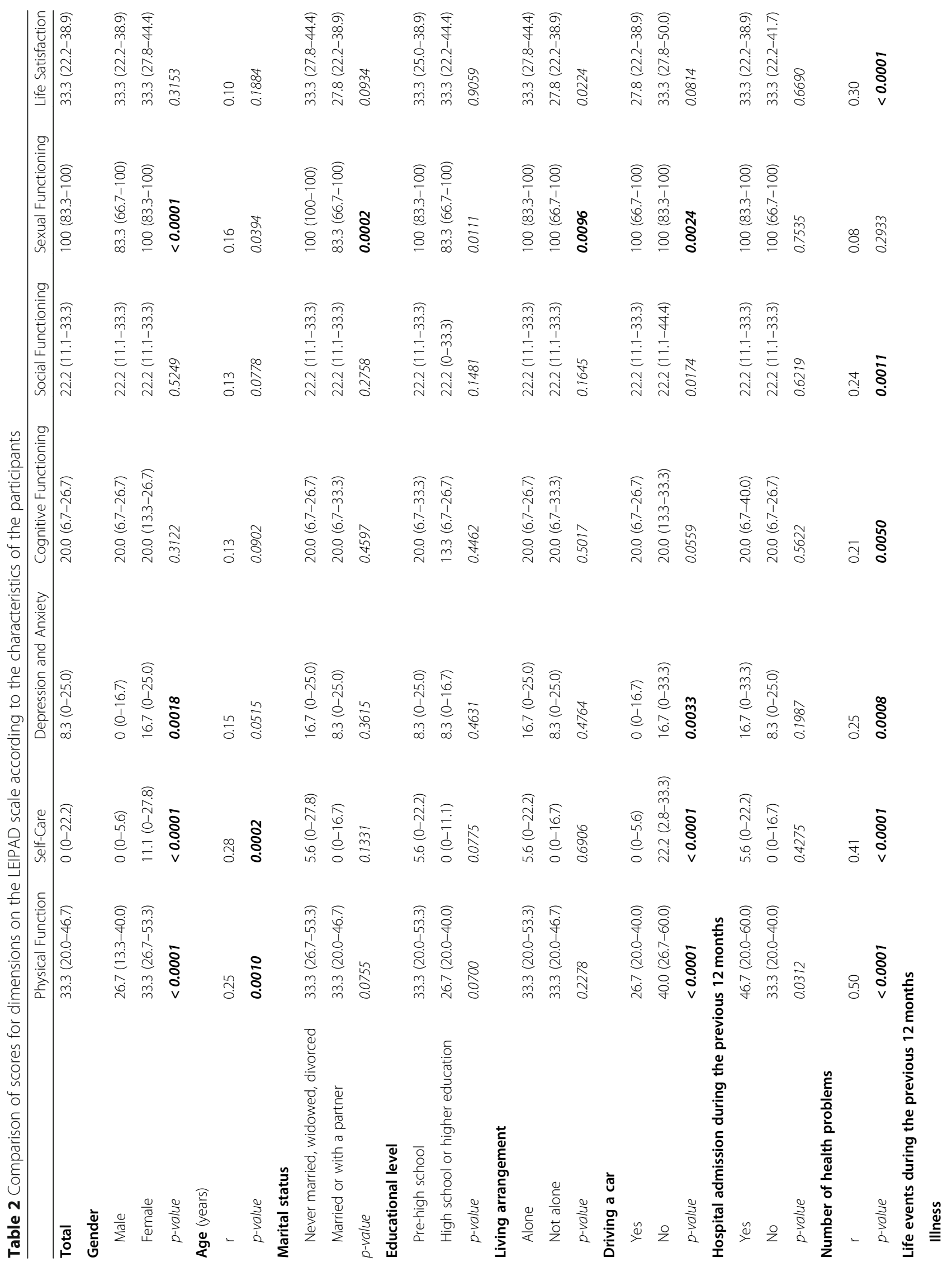




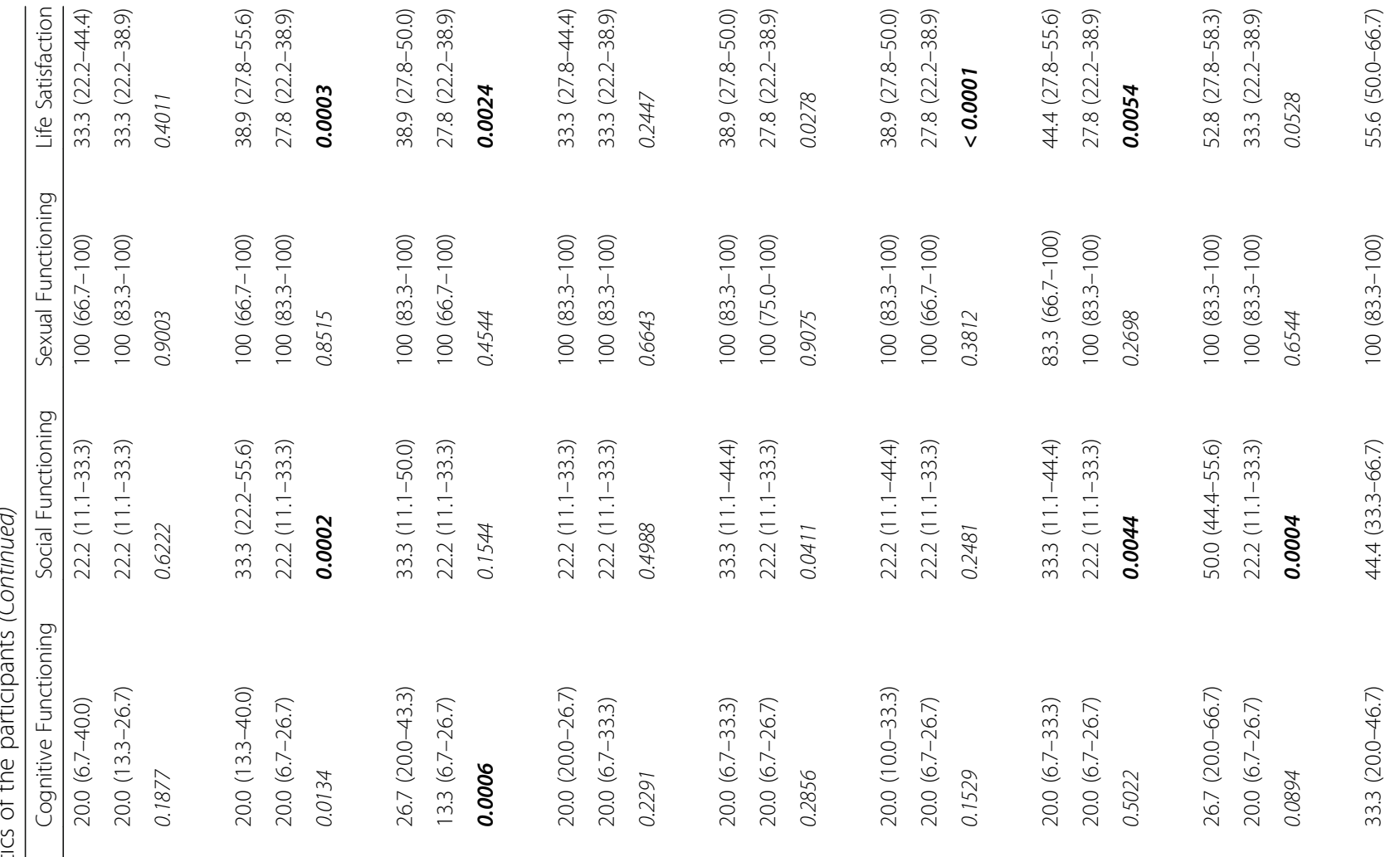

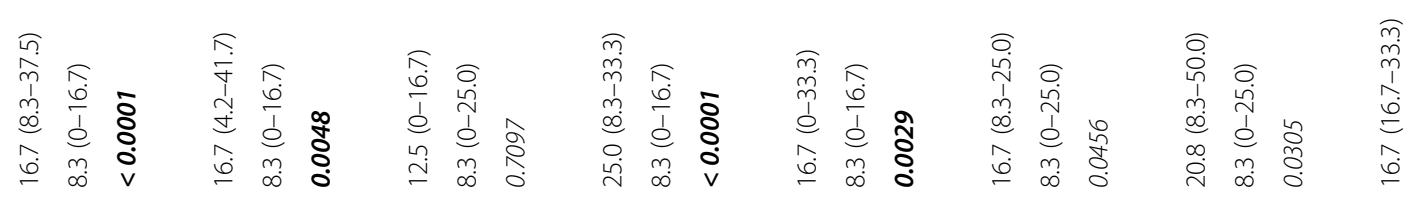

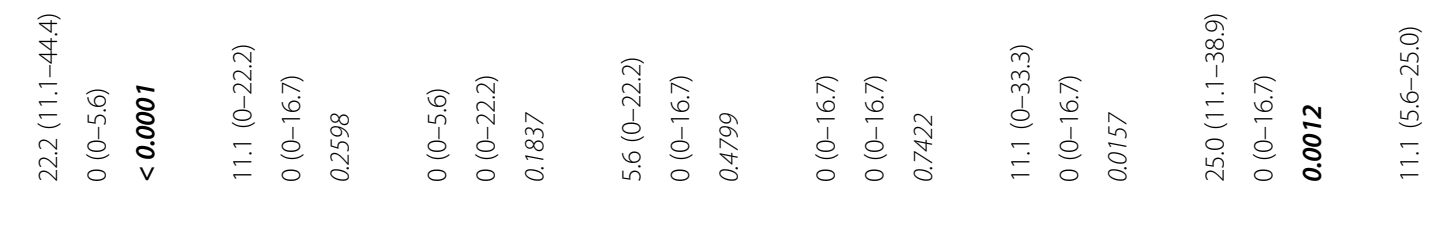

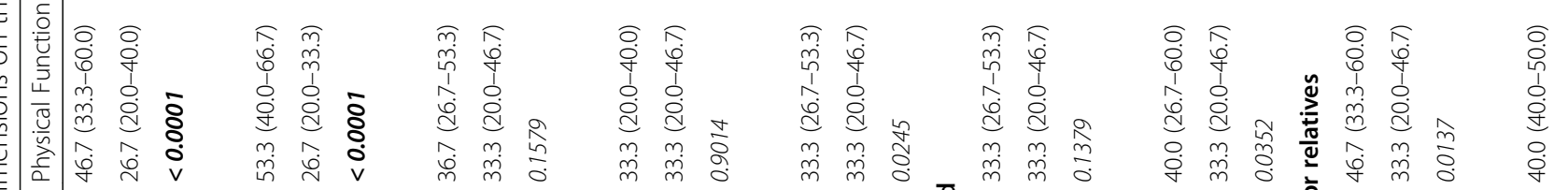




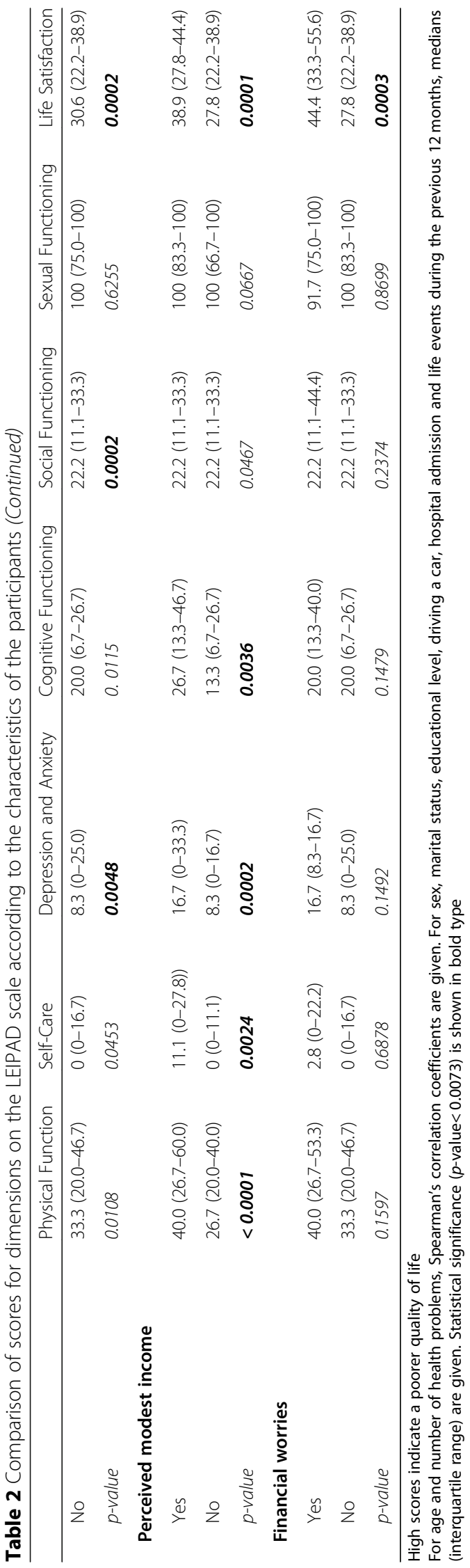


unsatisfactory, income perceived as modest and financial worries were self-reported by participants and recorded. The variables analyzed were those that were studied and that had an impact on the HRQoL of communitydwelling elderly people aged 65 years and over $[5,19]$.

HRQoL was assessed by the LEIPAD questionnaire, a brief self-administered questionnaire for communitydwelling people aged 65 years and over [17] that allows an easy individual assessment of older people's HRQoL and can be used for medical and psychosocial interventions [17]. The questionnaire is composed of 31 items grouped into seven scales: 'Physical Function' (5 items), 'Self-Care' (6 items), 'Depression and Anxiety' (4 items), 'Cognitive Functioning' (5 items), 'Social Functioning' (3 items), 'Sexual Functioning' (2 items) and 'Life Satisfaction' (6 items). All items are rated on a 4-point Likert scale, going from 0 (best HRQoL) to 3 (worst). A total score is calculated for each scale by adding up the individual scores of the items (provided that answers are given to all the questions). The score is then converted on a linear scale from 0 to 100 , with lower scores indicating a better HRQoL. Its psychometric qualities have been widely demonstrated $[16-18,20]$. A French version of the questionnaire was validated by our team specifically for use among community-dwelling people aged 80 years and above [18]. It showed very good acceptability, with response rates to each of the LEIPAD scales greater than $88 \%$. Good internal consistency (Cronbach's alpha ranging from 0.68 to 0.87 ) and strong test-retest reliability of the LEIPAD scales (intraclass correlation coefficients ranging from 0.77 to $0.95)$ were found.

\section{Statistical analyses}

SAS v9.4 was used for all the statistical analyses. Statistical significance was set at $p$-value $<0.05$.

Continuous data were expressed as the means and standard deviations (SD) or medians and interquartile range (IQR), and categorical data as frequencies and percentages.

Participants' marital status, educational level, living status, ability to drive and hospital admission during the previous 12 months were compared according to gender and age by Chi-square tests and non-parametric MannWhitney tests, respectively. Current health problems according to the ICD-10 classification were compared according to gender by Chi-square tests or Fisher exact tests. The number of health problems was compared according to gender by non-parametric Mann-Whitney tests.

Bivariate associations between continuous scores on the LEIPAD scales (non-normal distributions) and participants' characteristics (sociodemographic characteristics, self-reported health problems and life events in the previous 12 months) were analysed by non-parametric Mann-Whitney tests and Spearman's correlation coefficients (to estimate correlations between age and scores). Multiple group comparison tests of the LEIPAD scales were performed with a Bonferroni correction, resulting in a corrected significant $p$ value of $p=0.0073$.

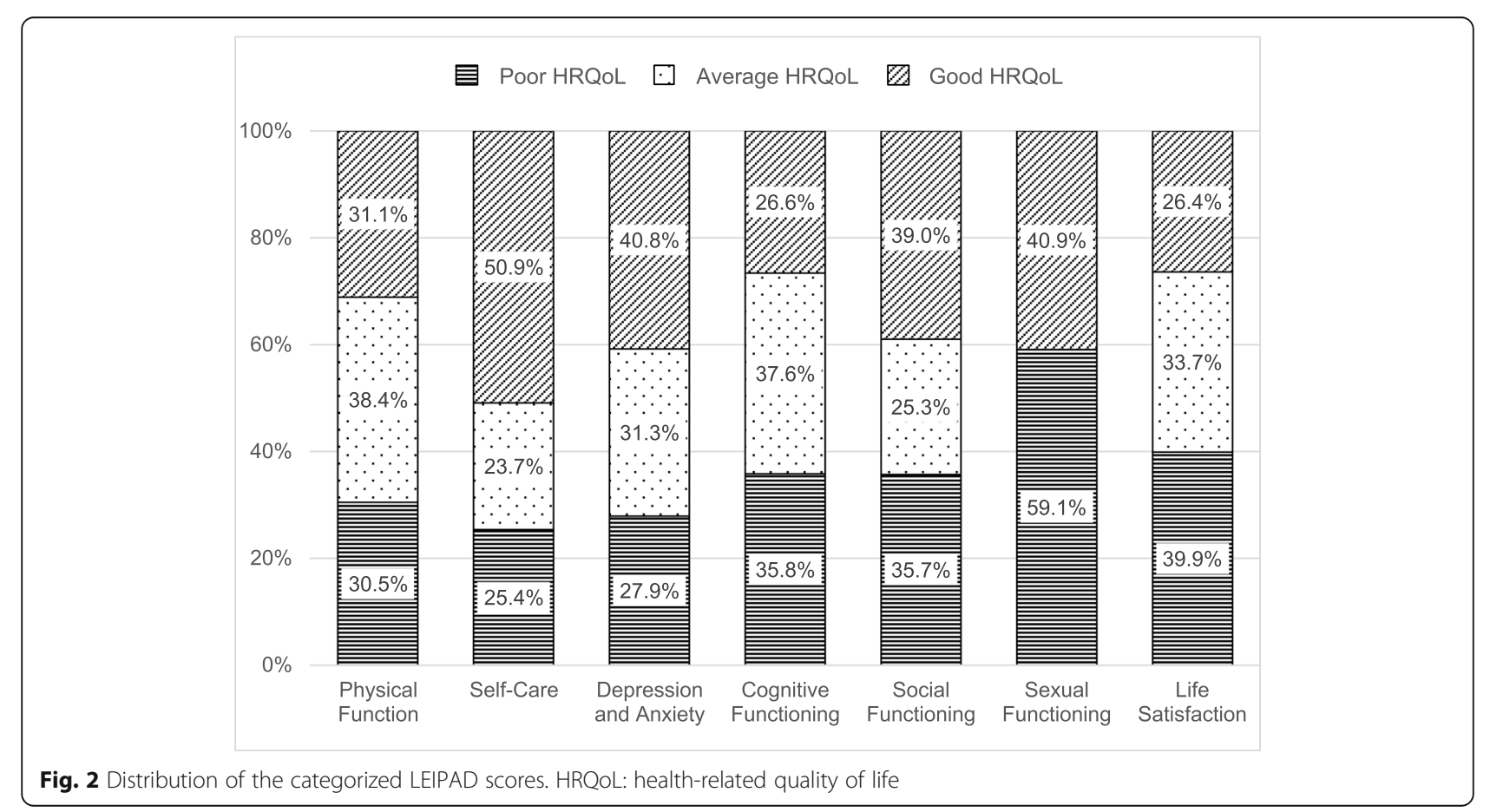


Table 3 LEIPAD 'Physical Function' scale: ordinal logistic regressions (cumulative logit models)

\begin{tabular}{|c|c|c|c|c|c|}
\hline & \multirow[b]{2}{*}{ Prevalence of 'poor' HRQoL (\%) } & \multicolumn{2}{|l|}{$\begin{array}{l}\text { Bivariate ordinal } \\
\text { logistic regression }\end{array}$} & \multicolumn{2}{|c|}{ Multivariate ordinal logistic regression ${ }^{a}$} \\
\hline & & $\mathrm{OR}(95 \% \mathrm{Cl})$ & $p$-value & $\mathrm{AOR}(95 \% \mathrm{Cl})$ & $p$-value \\
\hline \multicolumn{6}{|l|}{ Gender } \\
\hline Male & 17.7 & Ref & & Ref & \\
\hline Female & 40.8 & $2.78(1.58-4.90)$ & 0.0004 & $1.99(1.02-3.89)$ & 0.0439 \\
\hline \multicolumn{6}{|l|}{ Age } \\
\hline (years) & $84.9(3.6)^{b}$ & $1.10(1.04-1.17)$ & 0.0019 & $1.13(1.02-1.26)$ & 0.0187 \\
\hline \multicolumn{6}{|l|}{ Marital status } \\
\hline Married or with a partner & 27.2 & Ref & & & \\
\hline Never-married, widowed, divorced & 33.3 & $1.58(0.91-2.77)$ & 0.1076 & & \\
\hline \multicolumn{6}{|l|}{ Educational level } \\
\hline High school or higher education & 17.9 & Ref & & Ref & \\
\hline Pre-high school & 34.6 & $2.24(1.14-4.37)$ & 0.0187 & $2.62(1.21-5.68)$ & 0.0147 \\
\hline \multicolumn{6}{|l|}{ Driving a car } \\
\hline Yes & 17.3 & Ref & & & \\
\hline No & 49.3 & $3.45(1.90-6.27)$ & $<0.0001$ & & \\
\hline \multicolumn{6}{|c|}{ Hospital admission during the previous 12 months } \\
\hline No & 24.8 & Ref & & & \\
\hline Yes & 51.3 & $1.66(1.04-2.65)$ & 0.0354 & & \\
\hline Number of health problems & $5.6(1.9)^{b}$ & $1.74(1.47-2.07)$ & $<0.0001$ & $1.63(1.32-2.01)$ & $<0.0001$ \\
\hline \multicolumn{6}{|c|}{ Life events during the previous 12 months } \\
\hline \multicolumn{6}{|l|}{ Illness } \\
\hline No & 22.3 & Ref & & & \\
\hline Yes & 51.0 & $3.38(1.77-6.43)$ & 0.0002 & & \\
\hline \multicolumn{6}{|l|}{ Poor health } \\
\hline No & 15.4 & Ref & & Ref & \\
\hline Yes & 70.5 & $13.24(6.03-29.05)$ & $<0.0001$ & $9.22(3.84-22.11)$ & $<0.0001$ \\
\hline \multicolumn{6}{|l|}{ Daily care of a relative or friend } \\
\hline No & 28.3 & Ref & & & \\
\hline Yes & 35.7 & $1.57(0.74-3.33)$ & 0.2415 & & \\
\hline \multicolumn{6}{|l|}{ Bereavement } \\
\hline No & 27.3 & Ref & & & \\
\hline Yes & 36.8 & $1.58(0.81-3.10)$ & 0.1797 & & \\
\hline \multicolumn{6}{|c|}{ Serious illness of a relative or friend } \\
\hline No & 29.4 & Ref & & & \\
\hline Yes & 29.8 & $1.30(0.70-2.43)$ & 0.4045 & & \\
\hline \multicolumn{6}{|l|}{ Problems(s) with offspring } \\
\hline No & 27.3 & Ref & & & \\
\hline Yes & 40.7 & $1.97(0.91-4.25)$ & 0.0858 & & \\
\hline \multicolumn{6}{|c|}{ Relational problem(s) with friends or relatives } \\
\hline No & 27.6 & Ref & & & \\
\hline Yes & 60.0 & $4.74(1.28-17.49)$ & 0.0196 & & \\
\hline \multicolumn{6}{|l|}{ Unsatisfactory environment } \\
\hline No & 28.6 & Ref & & & \\
\hline
\end{tabular}


Table 3 LEIPAD 'Physical Function' scale: ordinal logistic regressions (cumulative logit models) (Continued)

\begin{tabular}{|c|c|c|c|c|c|}
\hline & \multirow[b]{2}{*}{ Prevalence of 'poor' HRQoL (\%) } & \multicolumn{2}{|c|}{$\begin{array}{l}\text { Bivariate ordinal } \\
\text { logistic regression }\end{array}$} & \multicolumn{2}{|c|}{ Multivariate ordinal logistic regression } \\
\hline & & $\mathrm{OR}(95 \% \mathrm{Cl})$ & $p$-value & AOR $(95 \% \mathrm{Cl})$ & $p$-value \\
\hline Yes & 41.7 & $2.32(0.76-7.02)$ & 0.1381 & & \\
\hline \multicolumn{6}{|c|}{ Perceived modest income } \\
\hline No & 20.4 & Ref & & & \\
\hline Yes & 49.1 & $3.47(1.84-6.54)$ & 0.0001 & & \\
\hline \multicolumn{6}{|c|}{ Financial worries } \\
\hline No & 28.2 & Ref & & & \\
\hline Yes & 41.2 & $1.94(0.76-4.95)$ & 0.1678 & & \\
\hline
\end{tabular}

Ordinal logistic regressions: (1) LEIPAD 'Physical Function' categorized score ('poor', 'average' or 'good' HRQoL) was used as the dependent variable. (2) Independent variables were entered as categorical variables except for age and number of health problems, which were entered as continuous variables. (3) $O R$ odds ratio; $\mathrm{Cl}$ confidence interval; $\mathrm{AOR}$ adjusted odds ratio

${ }^{\text {a }}$ Multiple regression: adjusted for sex, age and for all variables included in the model

${ }^{b}$ Mean (SD) in the 'poor' HRQoL category

Statistical significance is shown in bold type

Owing to their asymmetric and non-normal distributions, the LEIPAD scores could not be included as dependent variables in multiple linear regression models. Some authors have dichotomized HRQoL scores according to the lowest quartile $[21,22]$ or according to the median [23, 24]. The quartiles have also been used to categorize HRQoL scores into four classes [24]. We did not dichotomize LEIPAD HRQoL scores because we would have discarded too much valuable information. We evaluated the categorization in four classes according to quartiles but there were insufficient numbers in each category. Hence, we chose an intermediate solution, and LEIPAD HRQoL scores were categorized into three ordinal classes designated as 'poor', 'average' and 'good' HRQoL, according to the first and third quartiles. The EP who had lower scores (lower than or equal to the first quartile) were considered to have 'good' quality of life, those having higher scores (greater than or equal to the third quartile) to have 'poor' quality of life, and those having intermediate scores (greater than the first quartile and lower than the third quartile) to have 'average' quality of life.

Bivariate ordinal logistic regressions were performed to assess the association between participants' characteristics and LEIPAD scores categorized into the three ordinal classes. Crude odds ratios (OR), 95\% confidence interval $(\mathrm{CI})$ and its statistical significance were estimated. Finally, factors associated with HRQoL scores in the bivariate logistic regressions (found to be significant at the $p$-value level of 0.20 [25]) were included in multivariate ordinal logistic regression models using a forward selection, adjusting for gender and age. Adjusted odds ratio (AOR), 95\% CI and its statistical significance were estimated. Cumulative logit models were used to study associations between factors and poorer quality of life. The parallel-lines model assumptions were verified. If the cumulative logit model was rejected, the adjacent categories model was used.

\section{Results}

\section{Description of respondents}

The participation of EP in the study is described in Fig. 1.

The sociodemographic characteristics of the 184 EP recruited according to gender are given in Table 1. The participants were aged between 80 and 95 years: $61.4 \%$ between 80 and 84 years, $30.4 \%$ between 85 and 89 , and $8.2 \%$ between 90 and 95 . They were $2.8 \%$ never married, $58.6 \%$ married or living with a partner, $36.5 \%$ widowed and $2.2 \%$ divorced. The women were older than the men, were more often widowed, more often living alone and less likely to be driving. Those who were still driving were younger (83.2 years [SD 2.7] vs. 85.0 years [SD 3.8], $p=0.0009$ ). The rate of hospital admission in the previous 12 months was $26.1 \%$ in those aged $80-84$ years, $19.2 \%$ in those aged $85-89$ years and $13.3 \%$ in those aged 90-95 years. It did not differ according to the participants' gender $(p=0.1017)$ or age $(p=0.2279)$.

The events that had most frequently disrupted the life of the participants in the 12 months before the study are described in Table 1. There was no difference between women and men, except for perceived modest income and no difference according to age.

The health problems self-reported by the participants according to the ICD-10 classification are given in Supplementary Table 1. Almost all participants (97.8\%) mentioned at least one health problem, with 10 being the greatest number. The women reported significantly 
Table 4 LEIPAD 'Self-Care' scale: ordinal logistic regressions (cumulative logit models)

\begin{tabular}{|c|c|c|c|c|c|}
\hline & \multirow[b]{2}{*}{ Prevalence of 'poor' HRQoL (\%) } & \multicolumn{2}{|l|}{$\begin{array}{l}\text { Bivariate ordinal } \\
\text { logistic regression }\end{array}$} & \multicolumn{2}{|c|}{$\begin{array}{l}\text { Multivariate ordinal logistic } \\
\text { regression a }\end{array}$} \\
\hline & & $\overline{\mathrm{OR}}(95 \% \mathrm{Cl})$ & $p$-value & $\overline{A O R}(95 \% \mathrm{Cl})$ & $p$-value \\
\hline \multicolumn{6}{|l|}{ Gender } \\
\hline Male & 10.3 & Ref & & Ref & \\
\hline Female & 37.9 & $4.01(2.18-7.38)$ & $<0.0001$ & $2.10(0.82-5.38)$ & 0.1215 \\
\hline \multicolumn{6}{|l|}{ Age } \\
\hline (years) & $85.4(3.8)^{b}$ & $1.12(1.05-1.19)$ & 0.0002 & $1.10(0.98-1.23)$ & 0.1026 \\
\hline \multicolumn{6}{|l|}{ Marital status } \\
\hline Married or with a partner & 21.8 & Ref & & & \\
\hline Never-married, widowed, divorced & 29.6 & $1.61(0.91-2.87)$ & 0.1033 & & \\
\hline \multicolumn{6}{|l|}{ Educational level } \\
\hline High school or higher education & 13.2 & Ref & & & \\
\hline Pre-high school & 29.3 & $1.90(0.93-3.89)$ & 0.0787 & & \\
\hline \multicolumn{6}{|l|}{ Driving a car } \\
\hline Yes & 8.7 & Ref & & Ref & \\
\hline No & 51.6 & $7.71(4.03-14.78)$ & $<0.0001$ & $4.58(1.82-11.48)$ & 0.0012 \\
\hline \multicolumn{6}{|c|}{ Hospital admission during the previous 12 months } \\
\hline No & 24.6 & Ref & & & \\
\hline Yes & 31.6 & $1.38(0.70-2.71)$ & 0.3533 & & \\
\hline Number of health problems & $5.5(2.1)^{b}$ & $0.58(1.33-1.87)$ & $<0.0001$ & $1.37(1.10-1.72)$ & 0.0057 \\
\hline \multicolumn{6}{|c|}{ Life events during the previous 12 months } \\
\hline \multicolumn{6}{|l|}{ Illness } \\
\hline No & 21.8 & Ref & & & \\
\hline Yes & 34.7 & $2.17(1.16-4.06)$ & 0.0159 & & \\
\hline \multicolumn{6}{|l|}{ Poor health } \\
\hline No & 12.3 & Ref & & Ref & \\
\hline Yes & 60.5 & $12.40(5.83-26.38)$ & $<0.0001$ & $12.61(5.15-30.88)$ & $<0.0001$ \\
\hline \multicolumn{6}{|l|}{ Daily care of a relative or friend } \\
\hline No & 24.1 & Ref & & & \\
\hline Yes & 25.9 & $1.50(0.69-3.25)$ & 0.3041 & & \\
\hline \multicolumn{6}{|l|}{ Bereavement } \\
\hline No & 23.6 & Ref & & & \\
\hline Yes & 27.0 & $1.24(0.62-2.47)$ & 0.5493 & & \\
\hline \multicolumn{6}{|l|}{ Serious illness of a relative or friend } \\
\hline No & 24.4 & Ref & & & \\
\hline Yes & 24.4 & $0.76(0.39-1.48)$ & 0.4185 & & \\
\hline \multicolumn{6}{|l|}{ Problems(s) with offspring } \\
\hline No & 22.3 & Ref & & & \\
\hline Yes & 36.0 & $2.36(1.06-5.22)$ & 0.0350 & & \\
\hline \multicolumn{6}{|c|}{ Relational problem(s) with friends or relatives } \\
\hline No & 22.1 & Ref & & & \\
\hline Yes & 60.0 & $6.17(1.69-22.59)$ & 0.0060 & & \\
\hline \multicolumn{6}{|l|}{ Unsatisfactory environment } \\
\hline No & 23.7 & Ref & & & \\
\hline
\end{tabular}


Table 4 LEIPAD 'Self-Care' scale: ordinal logistic regressions (cumulative logit models) (Continued)

\begin{tabular}{|c|c|c|c|c|c|}
\hline & \multirow[b]{2}{*}{ Prevalence of 'poor' HRQoL (\%) } & \multicolumn{2}{|c|}{$\begin{array}{l}\text { Bivariate ordinal } \\
\text { logistic regression }\end{array}$} & \multicolumn{2}{|c|}{$\begin{array}{l}\text { Multivariate ordinal logistic } \\
\text { regression }^{\text {a }}\end{array}$} \\
\hline & & OR $(95 \% \mathrm{Cl})$ & $p$-value & AOR (95\% Cl) & $p$-value \\
\hline Yes & 33.3 & $2.37(0.79-7.06)$ & 0.1230 & & \\
\hline \multicolumn{6}{|c|}{ Perceived modest income } \\
\hline No & 18.8 & Ref & & & \\
\hline Yes & 36.5 & $2.61(1.39-4.88)$ & 0.0028 & & \\
\hline \multicolumn{6}{|c|}{ Financial worries } \\
\hline No & 23.6 & Ref & & & \\
\hline Yes & 31.3 & $1.26(0.48-3.31)$ & 0.6458 & & \\
\hline
\end{tabular}

Ordinal logistic regressions: (1) LEIPAD 'Self-Care' categorized score ('poor', 'average' or 'good' HRQoL) was used as the dependent variable. (2) Independent variables were entered as categorical variables, except for age and number of health problems which were entered as continuous variables. (3) $O R$ odds ratio; $C I$ confidence interval; $A O R$ adjusted odds ratio

a Multiple regression: adjusted for sex, age and for all variables included in the model

${ }^{b}$ Mean (SD) in the 'poor' HRQoL category

Statistical significance is shown in bold type

more health problems than the men. The number of health problems was not correlated with age $(r=0.06$, $p=0.4034)$. The most commonly cited diseases were those of the circulatory system, followed by disorders of the musculoskeletal system and connective tissue, and endocrine, nutritional and metabolic disorders. In addition, almost half of the participants reported visual disturbances or impairment or hearing impairment or deafness. Women reported more disorders of the musculoskeletal system and connective tissue and mental and behavioural disorders. Age was not related to health problems, except for mental and behavioural disorders for which participants were older (84.7 years (SD 3.4) vs. 83.6 years (SD 3.3), $p=0.0243$ ).

\section{Health-related quality of life}

The mean HRQoL scores of the LEIPAD scales are given in Table 2. High scores reflect a poorer HRQoL.

The highest score was found on the 'Sexual Functioning' scale, with $59.1 \%$ of participants having the maximum score of 100 . The answers showed that $61.2 \%$ were not interested in sexuality at all, $82.7 \%$ had no sexual activity and $14.5 \%$ occasionally.

Low scores, indicating better HRQoL, were obtained on the 'Self-Care' and 'Depression and Anxiety' scales with 50.9 and $40.8 \%$ of responders, respectively, having the minimum score of zero. The good responses obtained on the 'Self-Care' scale were due to the extent of the participants' autonomy since $85.1 \%$ were able to get dressed unaided, $98.9 \%$ to eat without help, $84.1 \%$ to take a bath or shower by themselves and $72.3 \%$ to go shopping alone. For the 'Depression and Anxiety' scale, $16.1 \%$ admitted to feeling anxious or very anxious and in $6.1 \%$ of cases the effect on them was strong or fairly strong. Of the $4.5 \%$ who felt depressed or very depressed, $5.1 \%$ considered the effects to be strong or fairly strong.

Overall, $92.3 \%$ of the participants were satisfied with their social contacts and relations with other people, $87.3 \%$ with the way in which they organised their free or leisure-time activities and $86.7 \%$ with their financial situation.

In comparison to their past life, $74.9 \%$ of responders were satisfied with their current circumstances. However, $54.4 \%$ considered the future would be worse or far worse, and for $57.5 \%$ of the EP the idea of the future prevented them from planning or achieving what they would like to do. The participants considered their general state of health to be good or very good (69.1\%), average $(28.7 \%)$ or bad $(2.2 \%)$.

Distributions of the categorized LEIPAD scores into three ordinal classes according to the first and third quartiles are shown in Fig. 2. The prevalence of 'poor' quality of life was $30.5 \%$ for the 'Physical Function' scale, $25.4 \%$ for the 'Self-Care' scale, $27.9 \%$ for the 'Depression and Anxiety' scale, $35.8 \%$ for the 'Cognitive Functioning' scale, $35.7 \%$ for the 'Social Functioning' scale, $59.1 \%$ for the 'Sexual Functioning' scale and $39.9 \%$ for the 'Life Satisfaction' scale. The categorized score of 'Sexual Functioning' was binary ('poor' versus 'good').

\section{Risk factors for impaired health-related quality of life} The LEIPAD continuous scores of the EP were compared by bivariate analysis according to gender, age, marital status, educational level, ability to drive, and hospital admission, number of health problems and life events during the previous 12 months (Table 2). 
Table 5 LEIPAD 'Depression and Anxiety' scale: ordinal logistic regressions (cumulative logit models)

\begin{tabular}{|c|c|c|c|c|c|}
\hline & \multirow[b]{2}{*}{ Prevalence of 'poor' HRQoL (\%) } & \multicolumn{2}{|c|}{$\begin{array}{l}\text { Bivariate ordinal } \\
\text { logistic regression }\end{array}$} & \multicolumn{2}{|c|}{ Multivariate ordinal logistic regression } \\
\hline & & OR $(95 \% \mathrm{Cl})$ & $p$-value & AOR (95\% Cl) & $p$-value \\
\hline \multicolumn{6}{|l|}{ Gender } \\
\hline Male & 22.0 & Ref & & Ref & \\
\hline Female & 33.0 & $2.44(1.40-4.27)$ & 0.0018 & $2.24(1.20-4.16)$ & 0.0111 \\
\hline \multicolumn{6}{|l|}{ Age } \\
\hline (years) & $84.4(3.4)^{b}$ & $1.06(0.98-1.16)$ & 0.1349 & $1.02(0.93-1.11)$ & 0.7051 \\
\hline \multicolumn{6}{|l|}{ Marital status } \\
\hline Married or with a partner & 28.8 & Ref & & & \\
\hline Never-married, widowed, divorced & 27.0 & $1.27(0.73-2.20)$ & 0.3939 & & \\
\hline \multicolumn{6}{|l|}{ Educational level } \\
\hline High school or higher education & 21.1 & Ref & & & \\
\hline Pre-high school & 30.2 & $1.39(0.71-2.71)$ & 0.3382 & & \\
\hline \multicolumn{6}{|l|}{ Driving a car } \\
\hline Yes & 21.5 & Ref & & & \\
\hline No & 37.9 & $2.48(1.39-4.42)$ & 0.0021 & & \\
\hline
\end{tabular}

Hospital admission during the previous 12 months

$\begin{array}{clll}\text { No } & 25.6 & \text { Ref } & \\ \text { Yes } & 36.6 & 1.47(0.77-2.80) & 0.2460 \\ \text { Number of health problems } & 5.2(2.0)^{\mathrm{b}} & 1.23(1.07-1.41) & \mathbf{0 . 0 0 4 3}\end{array}$

Life events during the previous 12 months

Illness

No $\quad 25.6$

Yes 35.3

Poor health

$\begin{array}{ll}\text { No } & 21.6 \\ \text { Yes } & 47.7\end{array}$

Daily care of a relative or friend

No

Yes

24.3

46.4

Bereavement

No

Yes

51.3

Serious illness of a relative or friend

No

22.5

Yes

41.7

Problems(s) with offspring

$\begin{array}{ll}\text { No } & 27.5 \\ \text { Yes } & 30.8\end{array}$

Relational problem(s) with friends or relatives
Ref

$1.90(1.04-3.49)$

0.0383

Ref

$3.42(1.77-6.61)$

0.0003

Ref

$2.56(1.27-5.13)$

0.0082

Ref

$2.57(1.20-5.51)$

0.0152

Ref

$3.78(1.89-7.55)$

0.0002

Ref

$3.09(1.48-6.42)$

0.0026

Ref Ref

$2.41(1.29-4.52)$

0.0060

$1.97(0.99-3.92)$

0.0526
26.6

50.0
No

Yes

Unsatisfactory environment

No

26.5
Ref

$1.88(0.87-4.08) \quad 0.1094$

Ref

$2.82(0.84-9.46) \quad 0.0939$

Ref 
Table 5 LEIPAD 'Depression and Anxiety' scale: ordinal logistic regressions (cumulative logit models) (Continued)

\begin{tabular}{|c|c|c|c|c|c|}
\hline & \multirow[b]{2}{*}{ Prevalence of 'poor' HRQoL (\%) } & \multicolumn{2}{|c|}{$\begin{array}{l}\text { Bivariate ordinal } \\
\text { logistic regression }\end{array}$} & \multicolumn{2}{|c|}{ Multivariate ordinal logistic regression } \\
\hline & & $\overline{\mathrm{OR}}(95 \% \mathrm{Cl})$ & $\overline{p \text {-value }}$ & $\overline{\mathrm{AOR}(95 \% \mathrm{Cl})}$ & $p$-value \\
\hline Yes & 46.2 & $3.25(1.10-9.60)$ & 0.0333 & & \\
\hline \multicolumn{6}{|c|}{ Perceived modest income } \\
\hline No & 23.1 & Ref & & & \\
\hline Yes & 39.2 & $2.24(1.21-4.15)$ & 0.0100 & & \\
\hline \multicolumn{6}{|c|}{ Financial worries } \\
\hline No & 29.6 & Ref & & & \\
\hline Yes & 12.5 & $1.12(0.60-2.09)$ & 0.7260 & & \\
\hline
\end{tabular}

Ordinal logistic regressions: (1) LEIPAD 'Depression and Anxiety' categorized score ('poor', 'average' or 'good' HRQoL) was used as the dependent variable. (2) Independent variables were entered as categorical variables, except for age and number of health problems which were entered as continuous variables. ( 3 ) $O R$ odds ratio; $\mathrm{Cl}$ confidence interval; $A O R$ adjusted odds ratio

a Multiple regression: adjusted for sex, age and for all variables included in the model

${ }^{b}$ Mean (SD) in the 'poor' HRQoL category

Statistical significance is shown in bold type

Multivariate ordinal logistic regressions were then performed to explore the factors associated with poorer quality of life. LEIPAD scores categorized into three ordinal classes ('poor', 'average' or 'good' HRQoL) were used as dependent variables, and the significant factors in bivariate ordinal logistic regressions $(p<0.20)$ were covariates adjusted for gender and age. Marital status and living arrangement could not be added in regressions together because of collinearity. We conducted separate analysis with these variables. As the results were the same, we chose to present the models including marital status (which was also the most significant in models).

For the 'Physical Function' scale (Table 3), being a woman, older age, pre-high school educational level, greater number of health problems and self-reported poor health during the previous 12 months were associated with poorer quality of life. For the 'Self-Care' scale (Table 4), not driving, greater number of health problems and reported poor health during the previous 12 months negatively affected quality of life. For the 'Depression and Anxiety' scale (Table 5), female EP who reported poor health, bereavement, and serious illness of a relative or friend during the past year were more likely to have poorer quality of life. For the 'Cognitive Functioning' scale (Table 6), not being able to drive and providing daily care for a relative or friend during the previous 12 months were associated with poorer quality of life. For the 'Social Functioning' scale (Table 7), the risk of being in a lower category (and hence of having poorer quality of life) increased with older age, when participants were not able to drive a car, when they reported relational problems with friends or relatives and an unsatisfactory environment during the previous year.
For the 'Sexual Functioning' scale (Table 8), nevermarried, widowed or divorced female EP with a pre-high school educational level were more likely to have poorer quality of life. Those who reported problems with offspring were more likely to have better quality of life in the sexual domain. For the 'Life Satisfaction' scale (Table 9), a serious illness of a relative or friend, unsatisfactory environment, perceived modest income and financial worries during the previous 12 months were associated with poorer quality of life.

\section{Discussion}

This study makes two main contributions to the previous literature on HRQoL in EP. It is the first to assess the HRQoL of community-dwelling people aged 80 years and over (who are often few in number or absent from studies or whose age group is not studied specifically) with the use of a self-administered questionnaire specifically adapted to EP, the LEIPAD scale. In addition, it deals in detail with the comorbidities and life events of this age group and their relation to HRQoL.

Our study was guided by several important methodological aspects.

- HRQoL was assessed with a questionnaire touching on various aspects of daily life specifically aimed at EP. It has been validated in French for use among different sample populations including communitydwelling people aged 80 years and above, and its psychometric qualities, notably construct validity, internal consistency and reproducibility, have been ascertained [16, 18, 20].

- Our sample size is to our knowledge, after a reference database search, the largest to be used in an European 
Table 6 LEIPAD 'Cognitive Functioning' scale: ordinal logistic regressions (cumulative logit models)

\begin{tabular}{|c|c|c|c|c|c|}
\hline & \multirow[b]{2}{*}{ Prevalence of 'poor' HRQoL (\%) } & \multicolumn{2}{|c|}{$\begin{array}{l}\text { Bivariate ordinal } \\
\text { logistic regression }\end{array}$} & \multicolumn{2}{|c|}{ Multivariate ordinal logistic regression } \\
\hline & & OR $(95 \% \mathrm{Cl})$ & $p$-value & AOR $(95 \% \mathrm{Cl})$ & $p$-value \\
\hline \multicolumn{6}{|l|}{ Gender } \\
\hline Male & 33.3 & Ref & & Ref & \\
\hline Female & 38.0 & $1.41(0.81-2.46)$ & 0.2202 & $0.62(0.29-1.33)$ & 0.2199 \\
\hline \multicolumn{6}{|l|}{ Age } \\
\hline (years) & $84.5(3.7)^{b}$ & $1.10(1.01-1.20)$ & 0.0237 & $1.08(0.99-1.19)$ & 0.0969 \\
\hline \multicolumn{6}{|l|}{ Marital status } \\
\hline Married or with a partner & 37.9 & Ref & & & \\
\hline Never-married, widowed, divorced & 32.4 & $0.89(0.50-1.56)$ & 0.6764 & & \\
\hline \multicolumn{6}{|l|}{ Educational level } \\
\hline High school or higher education & 34.2 & Ref & & & \\
\hline Pre-high school & 36.6 & $1.05(0.54-2.03)$ & 0.8915 & & \\
\hline \multicolumn{6}{|l|}{ Driving a car } \\
\hline Yes & 29.1 & Ref & & Ref & \\
\hline No & 46.0 & $1.98(1.10-3.58)$ & 0.0230 & $2.59(1.14-5.86)$ & 0.0226 \\
\hline
\end{tabular}

Hospital admission during the previous 12 months

\begin{tabular}{|c|c|c|c|c|c|}
\hline No & 34.9 & Ref & & & \\
\hline Yes & 41.0 & $1.17(0.60-2.27)$ & 0.6401 & & \\
\hline Number of health problems & $5.0(1.8)^{b}$ & $1.18(1.02-1.36)$ & 0.0266 & & \\
\hline \multicolumn{6}{|c|}{ Life events during the previous 12 months } \\
\hline \multicolumn{6}{|l|}{ Illness } \\
\hline No & 33.1 & Ref & & & \\
\hline Yes & 44.9 & $1.53(1.02-2.28)$ & 0.0397 & & \\
\hline \multicolumn{6}{|l|}{ Poor health } \\
\hline No & 32.0 & Ref & & & \\
\hline Yes & 48.8 & $1.82(0.95-3.50)$ & 0.0725 & & \\
\hline \multicolumn{6}{|c|}{ Daily care of a relative or friend } \\
\hline No & 32.1 & Ref & & Ref & \\
\hline Yes & 57.1 & $2.93(1.32-6.51)$ & 0.0082 & $3.30(1.44-7.58)$ & 0.0049 \\
\hline \multicolumn{6}{|l|}{ Bereavement } \\
\hline No & 32.8 & Ref & & & \\
\hline Yes & 48.6 & $1.49(0.75-2.95)$ & 0.2503 & & \\
\hline \multicolumn{6}{|c|}{ Serious illness of a relative or friend } \\
\hline No & 32.5 & Ref & & & \\
\hline Yes & 45.8 & $1.47(0.79-2.74)$ & 0.2292 & & \\
\hline \multicolumn{6}{|l|}{ Problems(s) with offspring } \\
\hline No & 34.5 & Ref & & & \\
\hline Yes & 46.2 & $1.34(0.61-2.91)$ & 0.4675 & & \\
\hline \multicolumn{6}{|c|}{ Relational problem(s) with friends or relatives } \\
\hline No & 35.3 & Ref & & & \\
\hline Yes & 55.6 & $1.95(0.54-7.03)$ & 0.3078 & & \\
\hline \multicolumn{6}{|l|}{ Unsatisfactory environment } \\
\hline No & 34.2 & Ref & & & \\
\hline
\end{tabular}


Table 6 LEIPAD 'Cognitive Functioning' scale: ordinal logistic regressions (cumulative logit models) (Continued)

\begin{tabular}{|c|c|c|c|c|c|}
\hline & \multirow[b]{2}{*}{ Prevalence of 'poor' HRQoL (\%) } & \multicolumn{2}{|l|}{$\begin{array}{l}\text { Bivariate ordinal } \\
\text { logistic regression }\end{array}$} & \multicolumn{2}{|c|}{ Multivariate ordinal logistic regression $^{a}$} \\
\hline & & OR $(95 \% \mathrm{Cl})$ & $\overline{p \text {-value }}$ & AOR (95\% Cl) & $p$-value \\
\hline Yes & 61.5 & $3.25(1.04-10.21)$ & 0.0431 & & \\
\hline \multicolumn{6}{|c|}{ Perceived modest income } \\
\hline No & 28.6 & Ref & & & \\
\hline Yes & 52.8 & $1.71(1.13-2.57)$ & 0.0106 & & \\
\hline \multicolumn{6}{|c|}{ Financial worries } \\
\hline No & 35.6 & Ref & & & \\
\hline Yes & 43.8 & $1.67(0.63-4.40)$ & 0.3025 & & \\
\hline
\end{tabular}

Ordinal logistic regressions: (1) LEIPAD 'Cognitive Functioning' categorized score ('poor', 'average' or 'good' HRQoL) was used as the dependent variable. (2) Independent variables were entered as categorical variables, except for age and number of health problems which were entered as continuous variables. ( 3 ) $O R$ odds ratio; $\mathrm{Cl}$ confidence interval; $\mathrm{AOR}$ adjusted odds ratio

aultiple regression: adjusted for sex, age and for all variables included in the model

${ }^{b}$ Mean (SD) in the 'poor' HRQoL category

Statistical significance is shown in bold type

study specifically focused on community-dwelling people aged 80 years and over whose HRQoL was assessed by a questionnaire specially adapted to their age group.

- Our study population was comparable to those in other published reports about French EP with regard to sociodemographic characteristics (French sample of 168 EP in the ESEMeD study) [13], living status [26, 27], ability to drive [28, 29], autonomy [30] and medical characteristics [27] except for the rate of eye diseases according to the ICD 10 classification, which was lower than that recorded in the general population of the same age [31], possibly because participants unable to complete the questionnaires unaided were not included in our study.

Some key points emerge from our study and are discussed in detail below: the declared HRQoL of EP aged 80 years of age and over was good for most dimensions but in certain domains was beginning to deteriorate, markedly so for the 'Sexual Functioning' scale; the female EP declared a significantly less satisfactory HRQoL in some domains; and some life events, other than health problems, negatively affected the HRQoL of EP in this age group.

The declared HRQoL of our study population was good for most dimensions but in certain domains was beginning to deteriorate. The best HRQoL score was obtained on the 'Self-Care' scale. This is an interesting finding because previous studies [13-15] used EQ-5D, in which self-care has a significant ceiling effect $[14,32]$. Our results are consistent with those of a French survey, Handicap Santé 2008 [33], that used other means of assessment and according to which life expectancy in France at 65 years with no restrictions of personal care activities was 15.6 years for men and 17.9 years for women. These concordant results can be explained by the fairly good autonomy of our community-dwelling participants, most of whom were able to eat meals, get dressed, take a bath or shower and do their shopping without assistance. Similar levels of autonomy were also observed in several French other surveys [27, 30, 34]. For the 'Physical Function' and the 'Self-Care' scales, a greater number of health problems and reported poor health during the previous 12 months negatively affected quality of life, which corroborates and complements previous data for these domains in studies of populations that were generally less elderly or that focused on specific diseases [11, 12, 35].

A large majority of the participants also had a good HRQoL score on the 'Depression and Anxiety' scale. The score was not correlated with age, as in five other studies [13-15, 36, 37]. Our results are in line with those observed in the dimension of anxiety and depression in the EQ-5D [13-15]. However, the LEIPAD scales give a more nuanced description of this domain in the very elderly owing to distinct assessments of anxiety and depression and to an appreciation at four levels of intensity not only of what the participants feel subjectively but also of the functional impact of these feelings on their lives, which is a key factor. Our results in this domain can be explained in part by the state of health and individual autonomy of the participants. The effects of health problems on depression and anxiety have been described in a younger age group [8]. We also observed that poor health, bereavement and the illness of a relative or friend are factors that negatively affect this domain of HRQoL in those aged 80 or over. Almost three 
Table 7 LEIPAD 'Social Functioning' scale: ordinal logistic regressions (adjacent categories models)

\begin{tabular}{|c|c|c|c|c|c|}
\hline & \multirow[b]{2}{*}{ Prevalence of 'poor' HRQoL (\%) } & \multicolumn{2}{|c|}{$\begin{array}{l}\text { Bivariate ordinal } \\
\text { logistic regression }\end{array}$} & \multicolumn{2}{|c|}{ Multivariate ordinal logistic regression $^{a}$} \\
\hline & & $\overline{\mathrm{OR}}(95 \% \mathrm{Cl})$ & $p$-value & $\overline{\mathrm{AOR}}(95 \% \mathrm{Cl})$ & $p$-value \\
\hline \multicolumn{6}{|l|}{ Gender } \\
\hline Male & 30.5 & Ref & & Ref & \\
\hline Female & 40.0 & $1.14(0.81-1.60)$ & 0.4590 & $0.61(0.36-1.04)$ & 0.0709 \\
\hline \multicolumn{6}{|l|}{ Age } \\
\hline (years) & $84.5(3.3)^{b}$ & $1.05(1.00-1.11)$ & 0.0595 & $1.07(1.00-1.14)$ & 0.0439 \\
\hline \multicolumn{6}{|l|}{ Marital status } \\
\hline Married or with a partner & 32.4 & Ref & & & \\
\hline Never-married, widowed, divorced & 39.2 & $1.20(0.85-1.70)$ & 0.2996 & & \\
\hline \multicolumn{6}{|l|}{ Educational level } \\
\hline High school or higher education & 30.8 & Ref & & & \\
\hline Pre-high school & 37.3 & $1.30(0.86-1.97)$ & 0.2168 & & \\
\hline \multicolumn{6}{|l|}{ Driving a car } \\
\hline Yes & 27.8 & Ref & & Ref & \\
\hline No & 47.8 & $1.57(1.09-2.25)$ & 0.0147 & $2.00(1.14-3.51)$ & 0.0155 \\
\hline
\end{tabular}

Hospital admission during the previous 12 months

$\begin{array}{clll}\text { Yes } & 31.7 & \text { Ref } & \\ \text { No } & 37.8 & 1.09(0.73-1.64) & 0.6703 \\ \text { Number of health problems } & 4.9(1.8)^{\mathrm{b}} & 1.14(1.05-1.25) & \mathbf{0 . 0 0 3 7}\end{array}$

Life events during the previous 12 months

Illness

Yes 32.7

No $\quad 38.2$

Poor health

$\begin{array}{ll}\text { No } & 29.1 \\ \text { Yes } & 57.8\end{array}$

Daily care of a relative or friend

No

Yes

32.9

53.6

\section{Bereavement}

No

31.1

Yes

53.8

Serious illness of a relative or friend

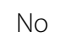

34.4

Yes

40.8

Problems(s) with offspring

$\begin{array}{ll}\text { No } & 31.9 \\ \text { Yes } & 59.3\end{array}$

Relational problem(s) with friends or relatives
32.9

90.0
Ref

$1.09(0.75-1.59) \quad 0.6444$

Ref

$1.92(1.26-2.92)$

0.0026

Ref

$1.29(0.80-2.08) \quad 0.2996$

Ref

$1.34(0.88-2.05) \quad 0.1726$

Ref

$1.06(0.72-1.56) \quad 0.7566$

Ref

$1.79(1.07-2.98)$

0.0261

Ref

$5.28(1.42-19.61)$

0.0129

Ref

$5.78(1.46-22.91)$

0.0126

Unsatisfactory environment 
Table 7 LEIPAD 'Social Functioning' scale: ordinal logistic regressions (adjacent categories models) (Continued)

\begin{tabular}{|c|c|c|c|c|c|}
\hline & \multirow[b]{2}{*}{ Prevalence of 'poor' HRQoL (\%) } & \multicolumn{2}{|c|}{$\begin{array}{l}\text { Bivariate ordinal } \\
\text { logistic regression }\end{array}$} & \multicolumn{2}{|c|}{ Multivariate ordinal logistic regression ${ }^{a}$} \\
\hline & & $\overline{\mathrm{OR}}(95 \% \mathrm{Cl})$ & $p$-value & $\overline{\mathrm{AOR}(95 \% \mathrm{Cl})}$ & $p$-value \\
\hline Yes & 84.6 & $3.67(1.43-9.43)$ & 0.0071 & $3.87(1.45-10.35)$ & 0.0070 \\
\hline \multicolumn{6}{|c|}{ Perceived modest income } \\
\hline No & 33.1 & Ref & & & \\
\hline Yes & 43.4 & $1.38(0.94-2.03)$ & 0.0985 & & \\
\hline \multicolumn{6}{|c|}{ Financial worries } \\
\hline No & 35.7 & Ref & & & \\
\hline Yes & 41.2 & $1.11(0.62-2.00)$ & 0.7214 & & \\
\hline
\end{tabular}

Ordinal logistic regressions: (1) LEIPAD 'Social Functioning' categorized score ('poor', 'average' or 'good' HRQoL) was used as the dependent variable. (2) Independent variables were entered as categorical variables, except for age and number of health problems which were entered as continuous variables. (3) $O R$ odds ratio; $\mathrm{Cl}$ confidence interval; $\mathrm{AOR}$ adjusted odds ratio

${ }^{\text {a }}$ Multiple regression: adjusted for sex, age and for all variables included in the model

b Mean (SD) in the 'poor' HRQoL category

Statistical significance is shown in bold type

quarters of our EP reported being satisfied with their current condition in comparison to their past life, feelings echoed in studies involving younger elderly participants $[8,38]$. The fact that half of our respondents were nevertheless pessimistic about their future can be explained by the strategy of "realistic expectations": the greater the gap between one's current situation and what one anticipates, the greater the risk of disappointment. To narrow this gap, the very elderly tend to revise their expectations downwards [39].

The 'Sexual Functioning' scale had the poorest HRQoL scores in the present study. Almost $60 \%$ of the respondents in the group had the highest score in this domain. However, this score did not significantly change as their age increased. Some studies have been made in the general population of the sexuality of EP up to the age of 78 years $[40,41]$ but to our knowledge only a very few studies of HRQoL have included the dimension of sexuality in the very elderly [42]. The response rate for items related to sexuality in our study was high (greater than 95\%). In study populations not older than 65 years, the rate is generally far lower. A response rate similar to ours was, however, obtained by Molzhan et al. [42], who reported only $8.7 \%$ missing data for items related to sexual activity. The correlations evidenced in our study are consistent with the following explanatory hypotheses, which can of course be combined and are not the only ones possible.

- The fact that there were more women among the participants and that they reported a significantly poorer HRQoL for the dimension concerned with sexual activity is in agreement with recent studies showing that sexuality differs according to gender [42],

- The marital status of people aged 80 years and over plays an important role. In our study only $58.6 \%$ of the participants were married or living with a partner, and "having or not having a partner is the best predictor of sexual activity, especially for elderly women" [43, 44].

The female EP in our study declared a significantly less satisfactory HRQoL on the 'Physical Function', 'Depression and Anxiety' and 'Sexual Functioning' scales in multivariate analysis, which confirms and complements previous findings for these domains in populations that were generally less elderly or whose quality of life was assessed by generic questionnaires [10, 13, 15, 45-49]. Our findings also showed that the female participants had specific problems related to ageing that could in part explain their less satisfactory HRQoL: they were older than the men, more often widowed and living alone, had a perceived modest income, were less likely to be driving and were suffering from significantly more health problems, as reported in previous studies [27, 31,37], in particular diseases of the musculoskeletal system and connective tissue and mental and behavioural disorders [50,51]. Our study refines the results presented by König, namely that female gender was associated with more problems in most of the EQ-5D dimensions [13]. In our previous study of EP aged 65 years and over [8], HRQoL did not differ significantly according to gender, apart from sexual activity, for which the women reported a less satisfactory HRQoL. It would appear, therefore, that differences between men and women in terms of HRQoL arise with advancing age, which is consistent with findings of the "Vie Quotidienne 
Table 8 LEIPAD 'Sexual Functioning' scale: binary logistic regressions

\begin{tabular}{|c|c|c|c|c|c|}
\hline & \multirow[b]{2}{*}{ Prevalence of 'poor' HRQoL (\%) } & \multicolumn{2}{|c|}{$\begin{array}{l}\text { Bivariate } \\
\text { logistic regression }\end{array}$} & \multicolumn{2}{|c|}{ Multivariate logistic regression } \\
\hline & & $\overline{\mathrm{OR}}(95 \% \mathrm{Cl})$ & $\overline{p \text {-value }}$ & $\mathrm{AOR}(95 \% \mathrm{Cl})$ & $p$-value \\
\hline \multicolumn{6}{|l|}{ Gender } \\
\hline Male & 43.8 & Ref & & Ref & \\
\hline Female & 71.9 & $3.29(1.76-6.15)$ & 0.0002 & $2.58(1.7-5.69)$ & 0.0183 \\
\hline \multicolumn{6}{|l|}{ Age } \\
\hline (years) & $84.3(3.5)^{b}$ & $1.10(0.99-1.21)$ & 0.0612 & $1.10(0.97-1.25)$ & 0.1349 \\
\hline \multicolumn{6}{|l|}{ Marital status } \\
\hline Married or with a partner & 47.6 & Ref & & Ref & \\
\hline Never-married, widowed, divorced & 76.1 & $3.50(1.79-6.83)$ & 0.0002 & $2.75(1.19-6.32)$ & 0.0176 \\
\hline \multicolumn{6}{|l|}{ Educational level } \\
\hline High school or higher education & 39.5 & Ref & & Ref & \\
\hline Pre-high school & 64.7 & $2.81(1.34-5.89)$ & 0.0062 & $2.92(1.24-6.89)$ & 0.0141 \\
\hline \multicolumn{6}{|l|}{ Driving a car } \\
\hline Yes & 50.9 & Ref & & & \\
\hline No & 70.3 & $2.28(1.18-4.40)$ & 0.0140 & & \\
\hline \multicolumn{6}{|c|}{ Hospital admission during the previous 12 months } \\
\hline No & 58.0 & Ref & & & \\
\hline Yes & 57.5 & $0.98(0.48-2.00)$ & 0.9539 & & \\
\hline Number of health problems & $4.5(2.0)^{b}$ & $1.01(0.87-1.18)$ & 0.8712 & & \\
\hline \multicolumn{6}{|c|}{ Life events during the previous 12 months } \\
\hline \multicolumn{6}{|l|}{ Illness } \\
\hline No & 60.5 & Ref & & & \\
\hline Yes & 54.0 & $0.77(0.39-1.49)$ & 0.4339 & & \\
\hline \multicolumn{6}{|l|}{ Poor health } \\
\hline No & 59.3 & Ref & & & \\
\hline Yes & 53.5 & $0.79(0.39-1.59)$ & 0.5033 & & \\
\hline \multicolumn{6}{|l|}{ Daily care of a relative or friend } \\
\hline No & 57.2 & Ref & & & \\
\hline Yes & 59.3 & $1.09(0.47-2.51)$ & 0.8472 & & \\
\hline \multicolumn{6}{|l|}{ Bereavement } \\
\hline No & 58.6 & Ref & & & \\
\hline Yes & 54.1 & $0.83(0.40-1.74)$ & 0.6229 & & \\
\hline \multicolumn{6}{|c|}{ Serious illness of a relative or friend } \\
\hline No & 56.0 & Ref & & & \\
\hline Yes & 61.2 & $1.24(0.63-2.45)$ & 0.5380 & & \\
\hline \multicolumn{6}{|l|}{ Problems(s) with offspring } \\
\hline No & 60.1 & Ref & & Ref & \\
\hline Yes & 44.4 & $0.53(0.23-1.22)$ & 0.1349 & $0.29(0.10-0.81)$ & 0.0186 \\
\hline \multicolumn{6}{|c|}{ Relational problem(s) with friends or relatives } \\
\hline No & 57.4 & Ref & & & \\
\hline Yes & 60.0 & $1.11(0.30-4.10)$ & 0.8729 & & \\
\hline \multicolumn{6}{|l|}{ Unsatisfactory environment } \\
\hline No & 57.2 & Ref & & & \\
\hline
\end{tabular}


Table 8 LEIPAD 'Sexual Functioning' scale: binary logistic regressions (Continued)

\begin{tabular}{|c|c|c|c|c|c|}
\hline & \multirow[b]{2}{*}{ Prevalence of 'poor' HRQoL (\%) } & \multicolumn{2}{|c|}{$\begin{array}{l}\text { Bivariate } \\
\text { logistic regression }\end{array}$} & \multicolumn{2}{|c|}{ Multivariate logistic regression ${ }^{a}$} \\
\hline & & OR $(95 \% \mathrm{Cl})$ & $\overline{p \text {-value }}$ & AOR (95\% Cl) & $p$-value \\
\hline Yes & 61.5 & $1.20(0.37-3.82)$ & 0.7635 & & \\
\hline \multicolumn{6}{|c|}{ Perceived modest income } \\
\hline No & 53.9 & Ref & & & \\
\hline Yes & 66.0 & $1.66(0.83-3.31)$ & 0.1506 & & \\
\hline \multicolumn{6}{|c|}{ Financial worries } \\
\hline No & 58.4 & Ref & & & \\
\hline Yes & 50.0 & $0.71(0.25-2.00)$ & 0.5203 & & \\
\hline
\end{tabular}

Binary logistic regressions: (1) LEIPAD 'Sexual Functioning' categorized score ('poor' versus 'good' HRQoL) was used as the dependent variable. (2) Independent variables were entered as categorical variables, except for age and number of health problems which were entered as continuous variables. (3) $O R$ odds ratio; $C I$ confidence interval; $A O R$ adjusted odds ratio

${ }^{a}$ Multiple regression: adjusted for sex, age and for all variables included in the model

${ }^{b}$ Mean (SD) in the 'poor' HRQoL category

Statistical significance is shown in bold type

et Santé" (vqs) survey of 2014, which suggested that in participants aged 75 years or over the situation is unfavourable for women in terms of functional impairments and limitations [27, 30]. The female EP also have a lower quality of life for the 'Self-care' dimension and, in multivariate models, a greater risk compared to men of having a deteriorated quality of life in this dimension. This is consistent with the fact that the total life expectancy at 65 years is longer in women compared to men, but that some of these "extra" years are with restrictions of personal care activities [6, 33]. Measuring HRQoL can be useful for studying the impact of some health problems, in particular diseases of the musculoskeletal system and mental and behavioral disorders, but also the establishment of actions and their impact on HRQoL in the health fields (prevention, screening, diagnosis and assessment, medical and psychosocial interventions, rehabilitation), the physical environment (for example, spaces and buildings accessible and useable by people with impairments, adjustment and improvement of elderly people's home) and community and health services (for example, home care, support for informal care) $[3,5]$.

We identified which particular domains of HRQoL in the very elderly, other than those related to health, are negatively affected by life events. For example, an unsatisfactory environment had a negative effect on the 'Social Functioning' and 'Life Satisfaction' scales. Not being able to drive had a negative effect on the 'Self-Care', 'Cognitive Functioning' and 'Social Functioning' scales. Incomes perceived as modest and financial worries during the previous 12 months were associated with a negative effect on the 'Life Satisfaction' scale. These findings are in line with those reported for EP aged between 65 and 75 years in studies of QoL $[52,53]$ and HRQoL [8] and enrich those of a study based on the EQ-5D in EP aged 75 years and over [13]. These findings can be useful during policy initiatives to create better age-friendly environments, whether in the field of outdoor environments (for example, support for community interaction and personal independence, places for recreation, physical activity and other leisure activities) or the domain of the social participation (for example, supportive environments for social exchange in the community). These findings can also be useful during policy initiatives concerning the domain of transport and mobility (for example, public transport, on-demand services and other support to improve mobility) [3]. As findings differ from one country to another, it is interesting to have recent data gathered in France.

\section{Limitations}

Of the people contacted to take part in our study, $14.1 \%$ responded favourably, a proportion close to that in other surveys of this type among the elderly [20]. The large dropout was certainly due to our recruitment method, as only letters were sent to participants, without phone or other face to face contacts to present the study. Our study have to be replicated in different settings and with a different method of participants' approach. It is likely that in the group of non-respondents there was a higher percentage of people with poorer health. Additionally, we excluded from analysis participants who had not replied to the questionnaire unaided. Thus, our population sample, and hence the study findings, are limited because the volunteer participants were particularly healthconscious or healthy. However, $69.1 \%$ of the participants considered their overall state of health to be good or excellent, a result in line with the findings of the Drees 
Table 9 LEIPAD 'Life Satisfaction' scale: ordinal logistic regressions (cumulative logit models)

\begin{tabular}{|c|c|c|c|c|c|}
\hline & \multirow[b]{2}{*}{ Prevalence of 'poor' HRQoL (\%) } & \multicolumn{2}{|c|}{$\begin{array}{l}\text { Bivariate ordinal } \\
\text { logistic regression }\end{array}$} & \multicolumn{2}{|c|}{ Multivariate ordinal logistic regression ${ }^{a}$} \\
\hline & & OR $(95 \% \mathrm{Cl})$ & $\overline{p \text {-value }}$ & AOR (95\% Cl) & $p$-value \\
\hline \multicolumn{6}{|l|}{ Gender } \\
\hline Male & 35.9 & Ref & & Ref & \\
\hline Female & 43.5 & $1.44(0.82-2.55)$ & 0.2085 & $1.32(0.69-2.55)$ & 0.4032 \\
\hline \multicolumn{6}{|l|}{ Age } \\
\hline (years) & $84.1(3.3)^{b}$ & $1.05(0.96-1.14)$ & 0.2971 & $1.02(0.93-1.13)$ & 0.6389 \\
\hline \multicolumn{6}{|l|}{ Marital status } \\
\hline Married or with a partner & 35.7 & Ref & & & \\
\hline Never-married, widowed, divorced & 45.2 & $1.55(0.86-2.80)$ & 0.1489 & & \\
\hline \multicolumn{6}{|l|}{ Educational level } \\
\hline High school or higher education & 47.1 & Ref & & & \\
\hline Pre-high school & 38.3 & $0.98(0.61-1.57)$ & 0.9269 & & \\
\hline \multicolumn{6}{|l|}{ Driving a car } \\
\hline Yes & 34.0 & Ref & & & \\
\hline No & 49.1 & $1.68(0.91-3.09)$ & 0.0952 & & \\
\hline
\end{tabular}

Hospital admission during the previous 12 months

$\begin{array}{llll}\text { No } & 41.9 & \text { Ref } & \\ \text { Yes } & 34.3 & 0.78(0.39-1.57) & 0.4897 \\ \text { Number of health problems } & 5.0(2.0)^{\mathrm{b}} & 1.29(1.11-1.51) & \mathbf{0 . 0 0 1 3}\end{array}$

Life events during the previous 12 months

Illness

No 41.6

Yes $\quad 37.2$

Poor health

$\begin{array}{ll}\text { No } & 34.5 \\ \text { Yes } & 57.9\end{array}$

Daily care of a relative or friend

No

34.9

Yes

63.0

Bereavement

No

35.8

Yes

54.5

Serious illness of a relative or friend

No

30.5

Yes

60.4

Problems(s) with offspring

No

35.9

Yes

63.6

Relational problem(s) with friends or relatives

$\begin{array}{ll}\text { No } & 38.6 \\ \text { Yes } & 62.5\end{array}$

Unsatisfactory environment

No

36.6
62.5
Ref

$0.92(0.48-1.75)$

0.7878

Ref

$2.67(1.31-5.46)$

0.0072

Ref

$3.20(1.39-7.38)$

0.0065

Ref

$1.90(0.91-3.94) \quad 0.0873$

Ref

$3.25(1.66-6.37)$

$0.0006 \quad 3.78(1.83-7.84)$

0.0003

$2.99(1.21-7.42) \quad 0.0179$

Ref

$2.64(0.63-11.02) \quad 0.1843$

Ref

Ref 
Table 9 LEIPAD 'Life Satisfaction' scale: ordinal logistic regressions (cumulative logit models) (Continued)

\begin{tabular}{|c|c|c|c|c|c|}
\hline & \multirow[b]{2}{*}{ Prevalence of 'poor' HRQoL (\%) } & \multicolumn{2}{|l|}{$\begin{array}{l}\text { Bivariate ordinal } \\
\text { logistic regression }\end{array}$} & \multicolumn{2}{|c|}{ Multivariate ordinal logistic regression $^{a}$} \\
\hline & & $\overline{\mathrm{OR}}(95 \% \mathrm{Cl})$ & $\overline{p \text {-value }}$ & $\overline{\mathrm{AOR}}(95 \% \mathrm{Cl})$ & $p$-value \\
\hline Yes & 81.8 & $7.31(1.57-33.95)$ & 0.0111 & $7.36(1.51-35.74)$ & 0.0134 \\
\hline \multicolumn{6}{|c|}{ Perceived modest income } \\
\hline No & 31.1 & Ref & & Ref & \\
\hline Yes & 59.6 & $3.45(1.75-6.81)$ & 0.0004 & $2.46(1.14-5.28)$ & 0.0211 \\
\hline \multicolumn{6}{|c|}{ Financial worries } \\
\hline No & 36.2 & Ref & & Ref & \\
\hline Yes & 73.3 & $5.44(1.62-18.21)$ & 0.0060 & $5.49(1.23-24.37)$ & 0.0253 \\
\hline
\end{tabular}

Ordinal logistic regressions: (1) LEIPAD 'Life Satisfaction' categorized score ('poor', 'average' or 'good' HRQoL) was used as the dependent variable. (2) Independent variables were entered as categorical variables, except for age and number of health problems which were entered as continuous variables. (3) $O R$ odds ratio; $C I$ confidence interval; $A O R$ adjusted odds ratio

aultiple regression: adjusted for sex, age and for all variables included in the model

${ }^{b}$ Mean (SD) in the 'poor' HRQoL category

Statistical significance is shown in bold type

survey on the state of health of the general population in France performed in 2012 and according to which 69\% of EP aged 85 years or over rated their overall state of health as "good" [54], and with a Finnish self-rated health study performed in 2009 [55]. The number of participants considering their state of health to be bad was very slightly lower than that in the vqs survey of 2014, which however included EP living in sheltered housing [27]. Currently in France, EP with severe loss of autonomy are very often housed in institutions, especially when they suffer from comorbid cognitive disorders [56]. The degree of autonomy of our participants was close to that described in French EP living at home [30].

We considered that the participants who were suffering from mental and behavioural disorders according to the ICD-10 classification were in fact suffering from psychiatric and not cognitive disorders since their treatment consisted solely of psychotropic drugs. We did not assess the cognitive status of the participants before they replied to the questionnaire but we discarded the questionnaires of those receiving treatment generally prescribed for cognitive disorders and those who did not complete the questionnaire unaided.

For some variables, there are few patients but our statistical tests took into account the small numbers in categories/variables if necessary. Our multivariate models were controlled for convergence. However, results on these variables had to be confirmed in larger samples.

\section{Conclusion}

Longer life expectancy presents numerous challenges, notably preserving the highest levels of HRQoL as long as possible. In our study, EP living at home who were aged 80 years and over reported good HRQoL in most domains except that of 'Sexual Functioning'. Their
HRQoL became worse when their health deteriorated. The female EP declared a significantly less satisfactory HRQoL. An unsatisfactory environment, not being able to drive, perceived modest income and financial worries negatively affected HRQoL. Identifying factors in our study that are potential determinants of HRQoL would be of direct benefit for individuals and could lead to concrete actions in public policy concerning health services (particularly home care, medical and psychosocial interventions, rehabilitation), means of transport (particularly public transport and on-demand services), living environment (particularly home improvement, spaces and buildings accessible and useable by elderly people including with impairments) and financial resources. Such initiatives would help improve the HRQoL of EP living at home until very old age.

\section{Supplementary information}

Supplementary information accompanies this paper at https://doi.org/10. 1186/s12955-020-01376-2.

Additional file 1: Table S1: Health problems self-reported by the participants according to the ICD-10 classification

\section{Acknowledgements}

The authors would like to thank the municipal staff of the communes helping with recruitment, all the elderly participants who agreed to take part in the study, R. Tourtauchaux for his liaison work with the municipalities and J. Watts for advice on the English version of the manuscript.

\section{Authors' contributions}

CA and IJ took part in drawing up the project. FR sent out the letters of invitation to take part in the study. CA performed computerization of the data and statistical analyses. CA and IJ were the major contributors in the writing of the manuscript. FR, SL and CR contributed to the writing of the manuscript. All authors read and approved the final manuscript.

\section{Funding}

The authors thank the teaching hospital $(\mathrm{CHU})$ of Clermont-Ferrand for its financial support. 


\section{Availability of data and materials}

The datasets used during the current study are available from the corresponding author on reasonable request.

\section{Ethics approval and consent to participate}

Approval of the study was granted 19/06/2012 by the ethics committee CECIC Rhône-Alpes-Auvergne, Grenoble, IRB 00005921. All those taking part in the study gave informed written consent.

\section{Consent for publication}

NA

\section{Competing interests}

The authors declare that they have no competing interests.

\section{Author details}

${ }^{1}$ Université Clermont Auvergne, CHU Clermont-Ferrand, Service de Psychiatrie de l'Adulte A et Psychologie Médicale, Centre Mémoire de Ressources et de Recherche, 58 rue Montalembert, Cedex 1, 63003 Clermont-Ferrand, France. ${ }^{2} \mathrm{CHU}$ Clermont-Ferrand, Service de Psychiatrie de I'Adulte A et Psychologie Médicale, Centre Mémoire de Ressources et de Recherche, Clermont-Ferrand, France. ${ }^{3} \mathrm{CHU}$ Clermont-Ferrand, Service de Psychiatrie de l'Adulte A et Psychologie Médicale, Clermont-Ferrand, France. ${ }^{4}$ Université Clermont Auvergne, CHU Clermont-Ferrand, CNRS, SIGMA Clermont, Institut Pascal, Clermont-Ferrand, France.

Received: 29 March 2019 Accepted: 23 April 2020

Published online: 07 May 2020

\section{References}

1. Eurostat - Statistics Explained. Structure et vieillissement de la population [Internet]. 2016 [cité 7 févr 2017]. Disponible sur: http://ec.europa.eu/ eurostat/statistics-explained/index.php/Population_structure_and_ageing/fr.

2. Eurostat - Statistics Explained. Statistiques sur la mortalité et l'espérance de vie [Internet]. 2016 [cité 7 févr 2017]. Disponible sur: http://ec.europa.eu/ eurostat/statistics-explained/index.php/Mortality_and_life_expectancy_ statistics/fr.

3. World Health Organisation Regional Office for Europe. Age-friendly environments in Europe. A handbook of domains for policy action. 2017. p. 160.

4. Vanleerberghe $P$, De Witte N, Claes C, Schalock RL, Verté D. The quality of life of older people aging in place: a literature review. Qual Life Res Int J Qual Life Asp Treat Care Rehabil. 2017;26(11):2899-907.

5. Roy N, Dubé R, Després C, Freitas A, Légaré F. Choosing between staying at home or moving: A systematic review of factors influencing housing decisions among frail older adults. PLOS ONE. 2018;13:1.

6. Eurostat - Statistics Explained. Statistiques sur les années de vie en bonne santé [Internet]. 2016 [cité 7 févr 2017]. Disponible sur: http://ec.europa.eu/ eurostat/statistics-explained/index.php/Healthy_life_years_statistics/fr.

7. Lin X-J, Lin I-M, Fan S-Y. Methodological issues in measuring health-related quality of life. Tzu Chi Med J. 2013;25(1):8-12.

8. Jalenques I, Auclair C, Rondepierre F, Gerbaud L, Tourtauchaux R. Healthrelated quality of life evaluation of elderly aged 65 years and over living at home. Rev Epidemiol Sante Publique. 2015:63(3):183-90.

9. Bilgili N, Arpacı F. Quality of life of older adults in Turkey. Arch Gerontol Geriatr oct. 2014:59(2):415-21.

10. Hajian-Tilaki K, Heidari B, Hajian-Tilaki A. Health related quality of life and its socio-demographic determinants among Iranian elderly people: a population based cross-sectional study. J Caring Sci mars. 2017;6(1):39-47.

11. Gu J, Chao J, Chen W, Xu H, Zhang R, He T, et al. Multimorbidity and health-related quality of life among the community-dwelling elderly: a longitudinal study. Arch Gerontol Geriatr janv. 2018;74:133-40.

12. Campos ACV, Ferreira E, AMD V, Albala C. Aging, Gender and Quality of Life (AGEQOL) study: factors associated with good quality of life in older Brazilian community-dwelling adults. Health Qual Life Outcomes. 2014;12: 166.

13. König H-H, Heider D, Lehnert T, Riedel-Heller SG, Angermeyer MC, Matschinger $\mathrm{H}$, et al. Health status of the advanced elderly in six European countries: results from a representative survey using EQ-5D and SF-12. Health Qual Life Outcomes. 2010;8:143.
14. Luthy C, Cedraschi C, Allaz A-F, Herrmann FR, Ludwig C. Health status and quality of life: results from a national survey in a community-dwelling sample of elderly people. Qual Life Res Int J Qual Life Asp Treat Care Rehabil. 2015:24(7):1687-96.

15. Mangen M-JJ, Bolkenbaas M, Huijts SM, van Werkhoven CH, Bonten MJM, de Wit GA. Quality of life in community-dwelling Dutch elderly measured by EQ-5D-3L. Health Qual Life Outcomes. 2017;15(1):3.

16. Haywood KL, Garratt AM, Fitzpatrick R. Older people specific health status and quality of life: a structured review of self-assessed instruments. J Eval Clin Pract août. 2005;11(4):315-27.

17. De Leo D, Diekstra RF, Lonnqvist J, Trabucchi M, Cleiren MH, Frisoni GB, et al. LEIPAD, an internationally applicable instrument to assess quality of life in the elderly. Behav Med Wash DC. 1998;24(1):17-27.

18. Jalenques I, Guiguet-Auclair C, Gerbaud L, Rachez C, Rondepierre F. Validation of the French version of the LEIPAD in community-dwelling people aged 80 years and above. PLoS One. 2019;14(3):e0213907.

19. Kim GM, Hong MS, Noh W. Factors affecting the health-related quality of life in community-dwelling elderly people. Public Health Nurs Boston Mass. 2018:35(6):482-9.

20. Jalenques I, Auclair C, Roblin J, Morand D, Tourtauchaux R, May R, et al. Cross-cultural evaluation of the French version of the LEIPAD, a healthrelated quality of life instrument for use in the elderly living at home. Qual Life Res Int J Qual Life Asp Treat Care Rehabil. 2013;22(3):509-20.

21. Teles MAB, Barbosa MR, Vargas AMD, Gomes VE, Ferreira EF, de BL MAME. et al. Psychosocial work conditions and quality of life among primary health care employees: a cross sectional study. Health Qual Life Outcomes. 2014; 12(1):72.

22. Nezu S, Okamoto N, Morikawa M, Saeki K, Obayashi K, Tomioka K, et al. Health-related quality of life (HRQOL) decreases independently of chronic conditions and geriatric syndromes in older adults with diabetes: the Fujiwara-kyo study. J Epidemiol. 2014;24(4):259-66.

23. Mbalinda SN, Kiwanuka N, Kaye DK, Eriksson LE. Reproductive health and lifestyle factors associated with health-related quality of life among perinatally HIV-infected adolescents in Uganda. Health Qual Life Outcomes. 2015;13:170

24. Sun L, Wong HM, McGrath CPJ. The factors that influence oral healthrelated quality of life in young adults. Health Qual Life Outcomes. 2018; 16(1):187.

25. Hosmer DW, Lemeshow S. Applied logistic regression. New York: Wiley; 2000.

26. FNORS. Vieillissement des populations et état de santé les régions de France [Internet]. Ministère de la Santé, de la Jeunesse, des Sports et de la Vie associative:; 2008 [cité 7 févr 2017]. (Les études du réseau des ORS). Disponible sur: http://www.fnors.org/uploadedFiles/vieillissement.pdf.

27. Directions de la Recherche. des Etudes de l'Evaluation et des Statistiques. Enquête Vie Quotidienne et Santé 2014 : Résultats Départementaux. Ministère des Affaires sociales et de la Santé; 2016. p. 215.

28. Pochet $P$. Mobilité et accès à la voiture chez les personnes âgées : évolutions actuelles et enjeux: Elsevier; 2003. p. 93-106. (Recherche, transports, sécurité). Report No.: 79.

29. Marie Dit Asse L, Fabrigoule C, Helmer C, Laumon B, Lafont S. Automobile driving in older adults: factors affecting driving restriction in men and women. J Am Geriatr Soc nov. 2014:62(11):2071-8.

30. Brunel $\mathrm{M}$, Carrère $\mathrm{A}$. Les personnes âgées dépendantes vivant à domicile en 2015 - Premiers résultats de l'enquête CARE « ménages ». Direction de la Recherche, des Etudes, de I'Evaluation et des Statistiques (DREES) - Ministère des Solidarités et de la Santé; 2017. Report No.: 1029.

31. Dourgnon P, Guillaume $S$, Rochereau T. Enquête sur la santé et la protection sociale 2010. Institut de recherche et documentation en économie de la santé; 2012 . Report No.: 553.

32. Perneger TV, Combescure C, Courvoisier DS. General population reference values for the French version of the EuroQol EQ-5D health utility instrument. Value Health J Int Soc Pharmacoeconomics Outcomes Res août. 2010;13(5):631-5.

33. Bouvier G. L'enquête Handicap-Santé, présentation générale [Internet]. INSEE; 2011 [cité 7 févr 2017]. Report No.: F1109. Disponible sur: https:// www.insee.fr/fr/statistiques/fichier/1380971/F1109.pdf.

34. Célant N, Guillaume S, Rochereau T. Enquête sur la santé et la protection sociale 2012. Paris: Institut de recherche et documentation en économie de la santé: 2015. Report No. 556 
35. Hajian-Tilaki K, Heidari B, Hajian-Tilaki A. Solitary and combined negative influences of diabetes, obesity and hypertension on health-related quality of life of elderly individuals: a population-based cross-sectional study. Diabetes Metab Syndr juin. 2016:10(2 Suppl 1):S37-42.

36. De Maria F. Qualité de vie des Franciliens de 60 ans ou plus : agir sur les limitations physiques. Ile de France: INSEE; 2007. p. 20-4. (Regards sur... la santé des Franciliens).

37. Observatoire Régional de la Santé de Basse-Normandie. Enquête santé des Bas-Normands : les personnes âgées de 65 ans et plus vivant à domicile. Observation Régional de la Santé; 2015.

38. Zimmermann-Sloutskis D, Moreau-Gruet F, Zimmerman E. Comparaison de la qualité de vie des personnes âgées vivant à domicile ou en institution. Neuchâtel: Observatoire Suisse de la Santé; 2012

39. Corten P. Qualité de vie et vieillissement: Université libre de Bruxelles; 2005.

40. Matthias RE, Lubben JE, Atchison KA, Schweitzer SO. Sexual activity and satisfaction among very old adults: results from a community-dwelling Medicare population survey. Gerontologist Févr. 1997:37(1):6-14.

41. Trudel G, Dargis L, Villeneuve L, Cadieux J, Boyer R, Préville M. Fonctionnement conjugal, sexuel et psychologique des couples aînés vivant à domicile : les résultats d'une enquête nationale avec méthodologie longitudinale (deuxième partie). Sexologies avr. 2014;23(2):52-68.

42. Molzahn A, Skevington SM, Kalfoss M, Makaroff KS. The importance of facets of quality of life to older adults: an international investigation. Qual Life Res Int J Qual Life Asp Treat Care Rehabil. 2010;19(2):293-8.

43. Kontula $\mathrm{O}$, Haavio-Mannila $\mathrm{E}$. The impact of aging on human sexual activity and sexual desire. J Sex Res févr. 2009;46(1):46-56.

44. Lindau ST, Schumm LP, Laumann EO, Levinson W, O'Muircheartaigh CA, Waite $L$. A study of sexuality and health among older adults in the United States. N Engl J Med. 2007;357(8):762-74.

45. Kind P, Dolan P, Gudex C, Williams A. Variations in population health status: results from a United Kingdom national questionnaire survey. BMJ. 1998; 316(7133):736-41.

46. Savoia E, Fantini MP, Pandolfi PP, Dallolio L, Collina N. Assessing the construct validity of the Italian version of the EQ-5D: preliminary results from a cross-sectional study in North Italy. Health Qual Life Outcomes. 2006; 4:47.

47. Blane D, Netuveli G, Montgomery SM. Quality of life, health and physiological status and change at older ages. Soc Sci Med 1982. 2008;66(7): 1579-87.

48. Saarni Sl, Härkänen T, Sintonen H, Suvisaari J, Koskinen S, Aromaa A, et al. The impact of 29 chronic conditions on health-related quality of life: a general population survey in Finland using 15D and EQ-5D. Qual Life Res Int J Qual Life Asp Treat Care Rehabil. 2006;15(8):1403-14.

49. Falsarella GR, Coimbra IB, Neri AL, Barcelos CC, Costallat LTL, Carvalho OMF, et al. Impact of rheumatic diseases and chronic joint symptoms on quality of life in the elderly. Arch Gerontol Geriatr. 2012;54(2):e77-82.

50. Baek S-R, Lim JY, Lim J-Y, Park JH, Lee JJ, Lee SB, et al. Prevalence of musculoskeletal pain in an elderly Korean population: results from the Korean longitudinal study on health and aging (KLoSHA). Arch Gerontol Geriatr. 2010;51(3):e46-51.

51. James NT, Miller CW, Fos PJ, Zhang L, Wall P, Welch C. Health status, physical disability, and obesity among adult Mississippians with chronic joint symptoms or doctor-diagnosed arthritis: findings from the Behavioral Risk Factor Surveillance System, 2003. Prev Chronic Dis. 2008;5(3):A85.

52. Netuveli G, Wiggins RD, Hildon Z, Montgomery SM, Blane D. Quality of life at older ages: evidence from the English longitudinal study of aging (wave 1). J Epidemiol Community Health avr. 2006:60(4):357-63.

53. Knesebeck OVD, Wahrendorf M, Hyde M, Siegrist J. Socio-economic position and quality of life among older people in 10 European countries: results of the SHARE study. Ageing Soc mars. 2007;27(02):269-84.

54. Directions de la Recherche, des Etudes de l'Evaluation et des Statistiques. L'état de santé de la population en France [Internet]. Ministère des Affaires sociales et de la Santé; 2015 [cité 7 févr 2017]. Report No.: Rapport 2015. Disponible sur: http://drees.social-sante.gouv.fr/etudes-et-statistiques/publications/recueilsouvrages-et-rapports/recueils-annuels/l-etat-de-sante-de-la-population/article/letat-de-sante-de-la-population-en-france-edition-2015.

55. Karppinen H, Pitkälä KH, Kautiainen H, Tilvis RS, Valvanne J, Yoder K, et al. Changes in disability, self-rated health, comorbidities and psychological wellbeing in community-dwelling 75-95-year-old cohorts over two decades in Helsinki. Scand J Prim Health Care sept. 2017:35(3):279-85.
56. Muller M. 728000 résidents en établissements d'hébergement pour personnes âgées en 2015. Drees: Ministère des Solidarités et de la Santé; 2017. (Etudes et résultats). Report No.: 1015.

\section{Publisher's Note}

Springer Nature remains neutral with regard to jurisdictional claims in published maps and institutional affiliations.
Ready to submit your research? Choose BMC and benefit from:

- fast, convenient online submission

- thorough peer review by experienced researchers in your field

- rapid publication on acceptance

- support for research data, including large and complex data types

- gold Open Access which fosters wider collaboration and increased citations

- maximum visibility for your research: over $100 \mathrm{M}$ website views per year

At $\mathrm{BMC}$, research is always in progress.

Learn more biomedcentral.com/submissions 